\title{
Jurassic syn-rift and Cretaceous syn-orogenic, coarse-grained deposits related to opening and closure of the Vahic (South Penninic) Ocean in the Western Carpathians - an overview
}

\author{
Dušan PLAŠIENKA
}

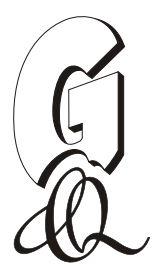

\begin{abstract}
Plašienka D. (2012) - Jurassic syn-rift and Cretaceous syn-orogenic, coarse-grained deposits related to opening and closure of the Vahic (South Penninic) Ocean in the Western Carpathians - an overview. Geol. Quart., 56 (4): 601-628, doi: 10.7306/gq.1044

Although no undoubted oceanic crustal rock complexes of Penninic affinity participate in the present surface structure of the Western Carpathians, indirect lines of evidence suggest prolongation of the South Penninic-Vahic oceanic tract into the ancient Carpathians. The sedimentary record of both the syn-rift and syn-orogenic clastic deposits reveal their origin between the outer Tatric (Austroalpine) and the inner Oravic (Middle Penninic) margins. The rifting regime is exemplified by the normal fault-related scarp breccias of the Jurassic Borinka Unit in the Malé Karpaty Mts., which are characterized by local, gradually denuded source areas. Two other regions provide examples of a contractional regime, both related to shortening and closure of the Vahic oceanic domain. The Belice Unit in the Považský Inovec Mts. includes Upper Jurassic-Lower Cretaceous eupelagic, mostly siliceous deposits and a thickening-upwards Senonian sequence of turbiditic sandstones, conglomerates and chaotic breccias. It is inferred that this succession represents the sedimentary cover of oceanic crust approaching a trench, its incorporation in the accretionary complex and finally underthrusting below the outer Tatric margin. In the Oravic units of the Pieniny Klippen Belt, deep-marine conglomerate/breccia bodies with olistoliths indicate collision-related thrust stacking that started from the Maastrichtian (Gregorianka Breccia of the Sub-Pieniny Unit) and terminated with the Lower Eocene Milpoš Breccia in the Šariš Unit. In addition, a tentative recycling scheme of "exotic" clastic material from mid-Cretaceous conglomerates of the Klape Unit to various Klippen Belt units is outlined. This material is considered to be unrelated to the Vahic oceanic realm and its closure, and likely represents erosional products of more distant orogenic zones.
\end{abstract}

Dušan Plašienka, Department of Geology and Palaeontology, Faculty of Natural Sciences, Comenius University, Mlynská dolina G, 842 15 Bratislava, Slovakia, e-mail: plasienka@fns.uniba.sk (received: May 22, 2012; accepted: July 20, 2012; first published online: October 31, 2012).

Key words: Western Carpathians, Mesozoic, rifting, thrusting, deep-marine clastics, mass-flow deposits.

\section{INTRODUCTION}

The easternmost surface exposures of the South Penninic Ocean (Ligurian-Piemont, "Alpine Tethys", or "Alpine Atlantic" - see Missoni and Gawlick, 2011), occur in the Ybbsitz Klippen Zone and probably also in the Rechnitz-Köszeg window at the eastern extremity of the Eastern Alps, just at the margin of the Pannonian Basin (Ratschbacher et al., 1990, 2004; Dunkl and Demény, 1997). There, however, distinguishing between the South and North Penninic branches is geologically irrelevant since these zones merge east of the Engadine window (e.g., Schmid et al., 2004, 2008). On the other hand, the northeastward continuation of the South Penninic units to the Western Carpathians is a matter of controversy. The evolution and composition of pre-Cenozoic units of the Eastern Alps and Western Carpathians show close relationships and are commonly ranged to the same Austroalpine tectonic system (e.g., Trümpy, 1988; Schmid et al., 2008; Froitzheim et al., 2008), which is first of all characterized by the pre-Gosauian (pre-Senonian) nappe structure. Accordingly, the northern Austroalpine margin of the Alps and Carpathians should involve units exhibiting similar attributes, including associations with the South Penninic oceanic complexes. Indeed, comparison of the Lower Austroalpine and the northern Tatric units substantiated their mutual correlation (Häusler et al., 1993; Plašienka, 1995a and references therein). Many analogies were found in the general evolutionary trend of these zones, as well as in numerous particular rock complexes or structures. Still, some doubts have remained, since the true oceanic Penninic units, including the Jurassic ophiolite complexes, do not participate in the surface structure of the Western Carpathians (e.g., 
Rakús and Hók, 2005). The reason clearly lies in the divergent patterns of Cenozoic evolution of the Alps and Carpathians; the former being governed by a strong continent/continent collision and subsequent uplift and erosion reaching mountain roots composed of the Penninic units (e.g., the Tauern window; Fig. 1), while the latter experienced mostly back-arc extension and only soft collision that was not capable of substantial uplift and exhumation of deeply buried Penninic complexes. This concept was applied to interpretation of deep seismic reflection lines and gravity models of the Western Carpathians (Tomek, 1993; Bielik et al., 2004) depicting the South Penninic suture as a flatly lying reflective channel underlying the Tatric thickskinned thrust sheet at mid-crustal levels. Following the Alpine model, any surface units suspected as remnants of the South Penninic accretionary complexes should be located along zones at the contact of the northern Austroalpine (Tatric in the Carpathians) margin with the Pieniny Klippen Belt, which is commonly interpreted as a relic of a continental fragment in a Middle Penninic position (e.g., Plašienka, 2003; Jurewicz, 2005; Froitzheim et al., 2008).

The aim of the present contribution is to review current information about the lithology, stratigraphy, structural and palaeogeographic position of coarse-grained deposits, that are presumably related to the opening and closing of an oceanic domain located beyond the northern Tatric margin in the Central Western Carpathians (CWC). We rely on mass-transport deposits containing coarse-grained material, since their source areas are more easily recognizable or at least definable; thus, they are very useful markers for palaeogeographic and palaeotectonic reconstructions. Instead of internal sedimentary structures and transport mechanisms, we focus on the composition and provenance of coarse material, inferred depositional environment, age relations and, if possible, on basin architecture and evolution. At the same time, an attempt is presented to clas- sify empirically differences between marine mass-flows related to extensional vs. contractional tectonic regimes and settings.

\section{MASS-TRANSPORT DEPOSITS AS VESTIGES OF ANCIENT PLATE MARGINS}

Actively deformed plate boundaries, including rift zones, trench-arc systems and prograding collisional belts, are sites of topographic irregularities with steep slopes and short distances between the mountainous areas and neighbouring deep sedimentary basins. In this situation, both endogenous (high uplift rates, seismicity) and exogenous (excessive rainfall and erosion rates) contribute to the rapid production of clastic material that is quickly transported to accumulate in adjoining depressions. As a result, the erosional products and ensuing deposits are often coarse-grained and poorly sorted. With lack of intervening environments, this material can be directly transported from the fault-controlled escarpments to bordering basins by some gravitationally driven mass-transport mechanism. Therefore associations and composition of coarse-grained deposits provide unique information about the structure and evolution of a particular orogenic zone. In the case of a longer river transport, the coarse classic material becomes rounded and enriched in resistant rocks, but still offers data on the structure and exhumation history of the source areas, including those completely destroyed or buried during the subsequent tectonic evolution.

Mass-transport (mass-flow, mass-wasting) deposits are considered here as stratiform bodies of mostly coarse-grained sediments emplaced by some gravity-driven mechanism and intercalated with more fine-grained deep-marine clastic or pelagic deposits. They include clast- or matrix-supported (blockin-matrix), conglomerate-dominated units variously named as

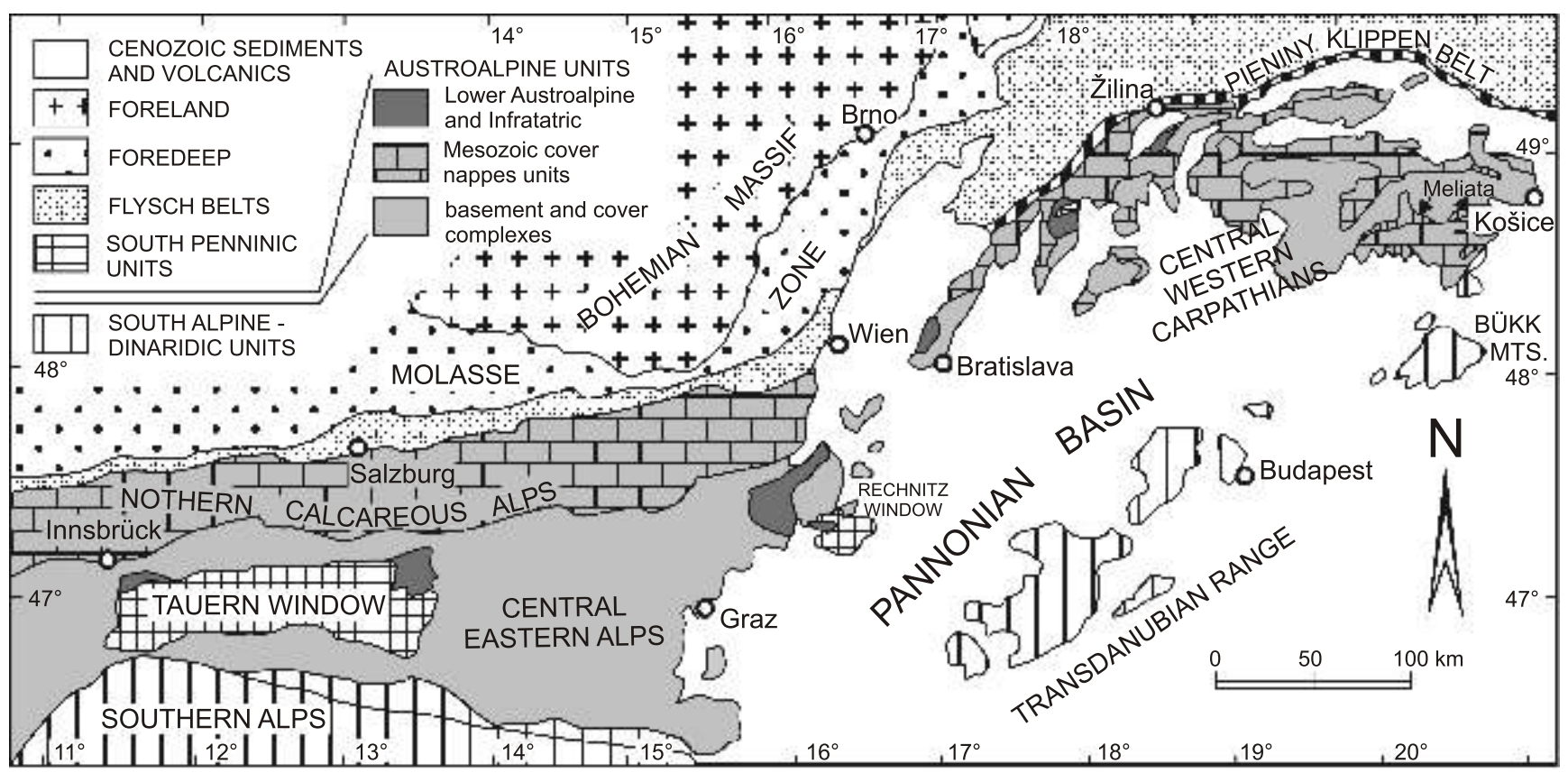

Fig. 1. Tectonic sketch map of the Eastern Alps and Western Carpathians showing location of the Lower Austroalpine-Infratatric elements in relation to the South Penninic units 
olistostromes, megabreccias, debris flows or debrites, pebbly mudstones, tilloid conglomerates, simmictites, diamictites, mixtites, scarp breccias, cliff breccias, submarine slumps, slides, rock falls or avalanches, sedimentary or gravitational mélanges, disorganized, mixed to chaotic complexes, argille scagliose and argille brecciate, tectonosedimentary breccias, wildflysch and broken formations. Some of these terms have a purely descriptive meaning, while others are used as genetic expressions referring to a particular type of transport and emplacement mechanism or derivation process. The common feature of all these sediments is that they were emplaced "en masse" during sudden, commonly tectonically induced events. Other typical attributes are their poor internal organization or even chaotic structure, various size of the extra-basinal clastic material ranging from microclasts to mega-olistoliths and areally restricted, lens-shaped appearance in sedimentary successions. It is assumed that they were usually initiated by some tectonic (earthquakes, tsunamis), or climatic events (strong storms and floods) causing failure of slope instabilities. The downslope moving masses may have been transported by various mechanisms (block sliding, grain flows, debris slumps, debris flows, and mudflows to high-density turbidity currents) through submarine channels, or as sheet-like slump bodies to a proximal position within the sedimentary basin.

Since mass-transport deposits are preferably accumulated in tectonically active environments, their original sedimentary structures are often overprinted by subsequent deformation. Sometimes the share of the sedimentary and tectonic fabric is hard to distinguish and such mixed rocks are commonly designated as mélanges. Some authors have attempted to distinguish the mélanges as tectonic units bounded by shear zones in contrast to olistostromes as stratigraphic units with depositional contacts (e.g., Hsü, 1974; Wang, 1981; Dimitrijević et al., 2003). However, most other authors use the term mélange in an essentially descriptive meaning for any rock formation with a blockin-matrix fabric and suggest the distinction of various genetic types of mélanges by adjectives such as tectonic, sedimentary, or diapiric (e.g., Silver and Beutner, 1980; Festa et al., 2010a, b).

Mass-transport deposits may occur in various situations and tectonic regimes. Generally, they are related to active tectonic settings producing high-energy relief that is prone to near-surface disintegration and mass movements induced by some triggering mechanism, commonly by seismic events. In extensional, rift-related near-shore situations, lithified or semi-lithified, pre-rift rock complexes are disintegrated by repeated brittle fracturing and seismic shaking to produce large masses of incoherent material that eventually suddenly moves downslope to the adjacent rift basin. The contractional settings of mass-flows are more diverse and include locations such as trench depressions or foredeeps, piggyback basins in accretionary wedges and fold-thrust belts, and fronts of individual thin- or thick-skinned thrust sheets. The source areas are usually exhumed, eroded and eventually destroyed more rapidly in compressional circumstances than in extensional. As a result the associated coarse-grained deposits are more diverse in structure and composition and often contain material that is considered as "exotic", i.e. derived from presently unrecognized areas or units. Another common feature of contraction-related mass-flow deposits is recurrent recycling of clastic material from older deposits that were already involved in thrusting and subsequently exposed to erosion.

Coarse-grained, marine syn-tectonic deposits have been described from many extensional settings in the world. For instance, olistostromes related to a passive margin and later to an accretionary wedge settings occurring in continuous sections were characterized by Liu and Einsele (1996) from the Tibetan Himalaya. Syn-rift deposits were described from the Devonian complexes of the Variscan belt (Füchtbauer and Richter, 1983) and of the Ural Mts. (Kopteva, 1981). A particularly rich literature is related to the opening of the South Penninic (Ligurian-Piemont) Ocean - e.g., Finger (1978), Dumont (1988), Eberli (1988), Froitzheim (1988), Häusler (1988), Bernoulli et al. (1993) and Marroni et al. (2002).

Subduction and collision-related olistostromes can be virtually found in all Phanerozoic orogenic belts, examples come e.g., from the Variscan belts of the Tien-Shan (Fedorov, 1987), Iberia (Maas and van Ginkel, 1983), Western Europe (Behr et al., 1982; Franke and Engel, 1986), the Eastern Alps and Western Carpathians (Ebner et al., 2008). Jurassic Neotethyan olistostromes and mélanges related to closure of the Meliata and Vardar oceanic zones have also been extensively described (Kovács, 1988; Kozur, 1991; Gawlick et al., 1999; Dimitrijević et al., 2003; Frisch and Gawlick, 2003; Kövér et al., 2009; Kovács et al., 2010; Haas et al., 2010; Missoni and Gawlick, 2011). Cretaceous to Paleogene syn-orogenic deposits in the Eastern Alps have been described by authors including Frisch et al. (1987), Decker et al. (1987), Faupl et al. (1987), Pober and Faupl (1988), Faupl and Wagreich (1992), Kurz et al. (1998), Wagreich $(2001,2003)$ and Ortner (2003). Further regional case studies come e.g., from the Eocene complexes of the Caucasus (Leonov, 1975) and Caribbean (Heubeck, 1992). In addition to the works cited later in this paper, an extensive dataset concerning the olistostromes and olistoliths of various ages and tectonic settings occurring in the External Western Carpathians (the Flysch Belt and the Pieniny Klippen Belt) was summarized by Cieszkowski et al. (2009).

However, the mass-wasting deposits that are most widespread onland probably occur in the Apennines, where they have been studied in detail during the last half-century and where several widely used terms have been coined (olistostrome, argille scagliose). The reference list from this area would be very long, but certainly it should contain the milestone papers by Abbate et al. (1970), Elter and Trevisan (1973), Naylor (1981) and Pini (1999).

For recent comprehensive reviews of literature sources, terminology, associations and processes related to mass-transport deposits, or mélanges in general, the reader is recommended especially to papers by Mutti et al. (2009), Camerlenghi and Pini (2009), Festa et al. (2010a, b), Vannucchi and Bettelli (2010) and Pini et al. (2012), and to the references quoted therein.

\section{GEOLOGICAL SETTING}

In the Eastern Alps, the transition from the Penninic Ocean to the Austroalpine margin is particularly well-exposed and studied in the Swiss Eastern Alps, where it is represented by the Platta-Arosa Zone and Lower Austroalpine Err-Bernina 
nappes, respectively (see e.g., Schmid et al., 2004 and references therein). In the Austrian Alps further east, the Penninic oceanic units are exposed in large tectonic windows exhumed from beneath the Austroalpine complexes - the Engadine, Tauern, and Rechnitz-Köszeg windows from the west to east. In the Western Carpathians, the South Penninic elements have largely disappeared from the surface, but several units clearly correlative with the Lower Austroalpine system are still present (Infratatric in Fig. 1). Thus, taking into account the structure and evolution of the principal Western Carpathian tectonic units in relation to their Alpine counterparts, it becomes clear that any vestiges of the South Penninic oceanic domains should be searched for in areas north of the outer Austroalpine margin and along the Central/External Carpathian boundary, i.e. generally along the Pieniny Klippen Belt (PKB) and its southern adjoining zones (e.g., Plašienka, 1995a, 1999; Plašienka et al., 1995, 1997; Froitzheim et al., 2008).

In this paper, I describe briefly the geological structure of four particular areas, which possess a geological record of opening and/or closure of a presumed oceanic tract that created an eastwards prolongation of the Alpine Atlantic: the Male Karpaty Mts., the Považský Inovec Mts., the Klape Unit in the Middle Váh Valley and Oravic units in the Pieniny sector of the PKB in eastern Slovakia (Fig. 2).

The CWC-Austroalpine (or Slovakocarpathian; Plašienka in Froitzheim et al., 2008) tectonic system embraces three major crustal-scale thrust sheets that involve the pre-Alpine crystalline basement and its locally Pennsylvanian to Permian, but mainly Mesozoic sedimentary cover - the Gemeric, Veporic and Tatric superunits from south to north and from top to bottom. These three basement-involved thrust sheets are overridden by three décollement cover nappe systems - the Fatric, Hronic and Silicic superunits (e.g., Andrusov, 1968). The tectonic assembly of these three main CWC superunits was completed during the Cretaceous, basically before the Senonian. Besides the Tatricum, only frontal elements of the Fatric, and in part also the Hronic Nappe systems reach the northern Austroalpine margin of the CWC. Due to its position and special composition, the outermost and lowermost partial Tatric element was distinguished as the so-called Infratatricum (Plašienka et al., 1997), which crops out in the Malé Karpaty Mts. (Borinka Unit), in the Považský Inovec Mts. (Inovec Nappe) and in the Malá Fatra Mts. (Kozol Unit; cf. Figs. 1 and 2). In particular, the first two units bear vestiges of rifting events related to opening of the Jurassic oceanic realms and will be characterized below.

In general, the Tatric and Fatric Mesozoic successions can be subdivided according to their relationships to the main tectonic processes. The pre-rift (pre-Jurassic) strata consist of Permian-Lower Triassic continental siliciclastic deposits, Middle Triassic carbonate platform and Upper Triassic continental-lagoonal clastic and evaporitic deposits of the Keuper facies and are terminated by Rhaetian shallow-marine carbonates. The Lower Jurassic syn-rift strata contain marine neritic and hemipelagic deposits with variable contents of terrigenous and biogenic detritus and are followed by post-rift, Middle Jurassic to Lower Cretaceous hemipelagic to eupelagic strata deposited partly below the CCD (Fig. 3). However, domains along the northern Tatric margin bear signatures of long-term extensional tectonic processes with several rifting pulses, especially those located in the vicinity of the North Tatric Ridge reconstructed in the westernmost Carpathian area. The Devín and Orešany basins may serve as examples (see below). Sedimentary successions of both the Tatric and Fatric superunits are terminated by the Albian-Cenomanian syn-orogenic, deep-marine terrigenous clastic "flysch" deposits (Poruba Formation; e.g., Jablonský, 1978), including conglomerates with "exotic" pebble material (Mišík et al., 1981).

The rather hypothetical prolongation of the South Penninic oceanic units into the Western Carpathians was designated as the Vahicum by Mahel' (1981). Originally he regarded the so-called Periklippen Zone in western Slovakia, and especially the thick prisms of mid-Cretaceous conglomeratic flysch of the Klape Unit as his Vahicum (Mahel', 1980, 1981). Later on, other units were included within the South Penninic-Vahic tectonic system - the Belice Unit in the Považský Inovec Mts. (Plašienka, 1995a, b, c) and the Iňačovce-Krichevo Unit known from boreholes reaching the substratum of the Transcarpathian Depression in eastern Slovakia (Soták et al., 1993a, 1994). The former is described in a more detail here; the latter consists of low-grade, Bündnerschiefer-type metasedimentary complexes of Mesozoic to Eocene age and slabs of serpentinite.

The Pieniny Klippen Belt (PKB) is a narrow (merely several $\mathrm{km}$ ), but lengthy (up to $600 \mathrm{~km}$ ) zone characterized by an intricate internal structure. It separates the External Western Carpathians ("Flysch Belt", North Penninic units, Paleogene/Neogene accretionary complex overriding the North European Platform) from the CWC (CWC-Austroalpine units, Cretaceous basement/cover nappe stack), and involves Jurassic to Paleogene deposits of very variable lithology. Over more than a century of detailed research, these have been subdivided into numerous lithostratigraphic and tectonic units of distant provenance, hence witnessing excessive shortening and subsequent dispersal within this restricted zone. The PKB is therefore often considered as a suture, in spite of a lack of ophiolite complexes. In many places, the PKB is formed by isolated blocks of "klippen" (resistant Middle Jurassic to Lower Cretaceous limestones) embedded in the "klippen mantle" (soft Lower Jurassic and Upper Cretaceous to Paleogene shales, marls and flysch deposits). Consequently, the PKB has frequently been characterized as a tectonic megabreccia, a mélange, and even as a huge chaotic sedimentary body - an olistostrome (Nemčok, 1980). However, the peculiar "block-in-matrix" structure of the PKB appears to be mostly the result of intense tectonic disintegration due to thrust stacking, imbrication and superimposed transpressional and transtensional movements.

Concerning its composition, the most distinctive feature of the PKB is the omnipresence of units characteristic of it, which were derived from an independent palaeogeographic zone of presumably Middle Penninic position, called the Oravicum (Mahel', 1986). This includes the ridge-related Czorsztyn and basinal Pieniny (Kysuca) successions in particular, but various "transitional" successions are present as well (e.g., Birkenmajer, 1977, 1986). The Oravic units only include detached Jurassic to Lower Eocene strata evolving from early Lower Jurassic terrigenous syn-rift clastic deposits (akin to the Gresten Fm.) and followed by late Early to early Middle Jurassic 


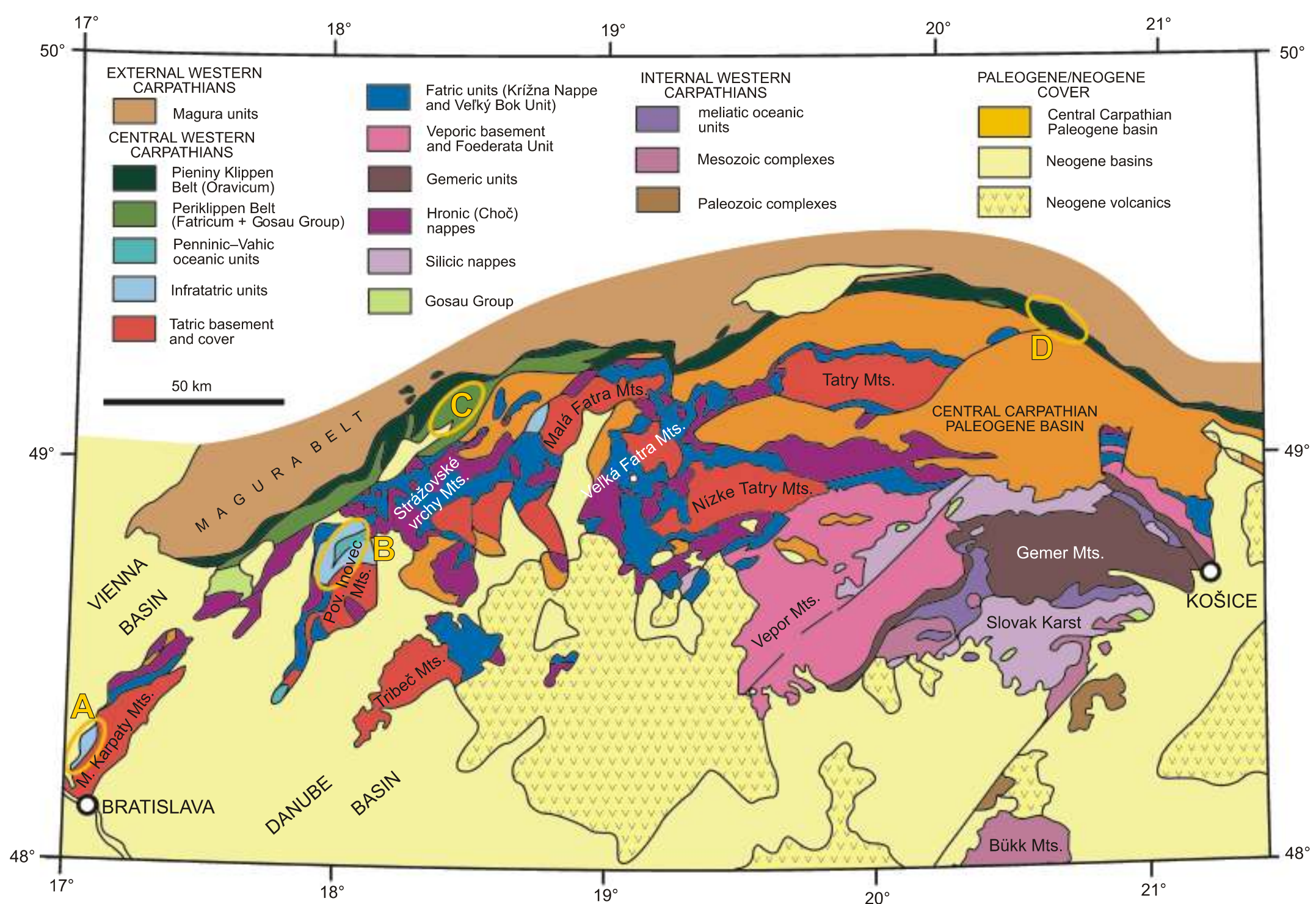

Fig. 2. Simplified tectonic map of the Western Carpathians

Ellipses indicate positions of areas described in the text: A - Borinka Unit in the Malé Karpaty Mts.; B - Belice Unit in the Považský Inovec Mts.; C - Klape Unit in the Middle Váh Valley; D - Slovakian Pieniny sector of the Klippen Belt 


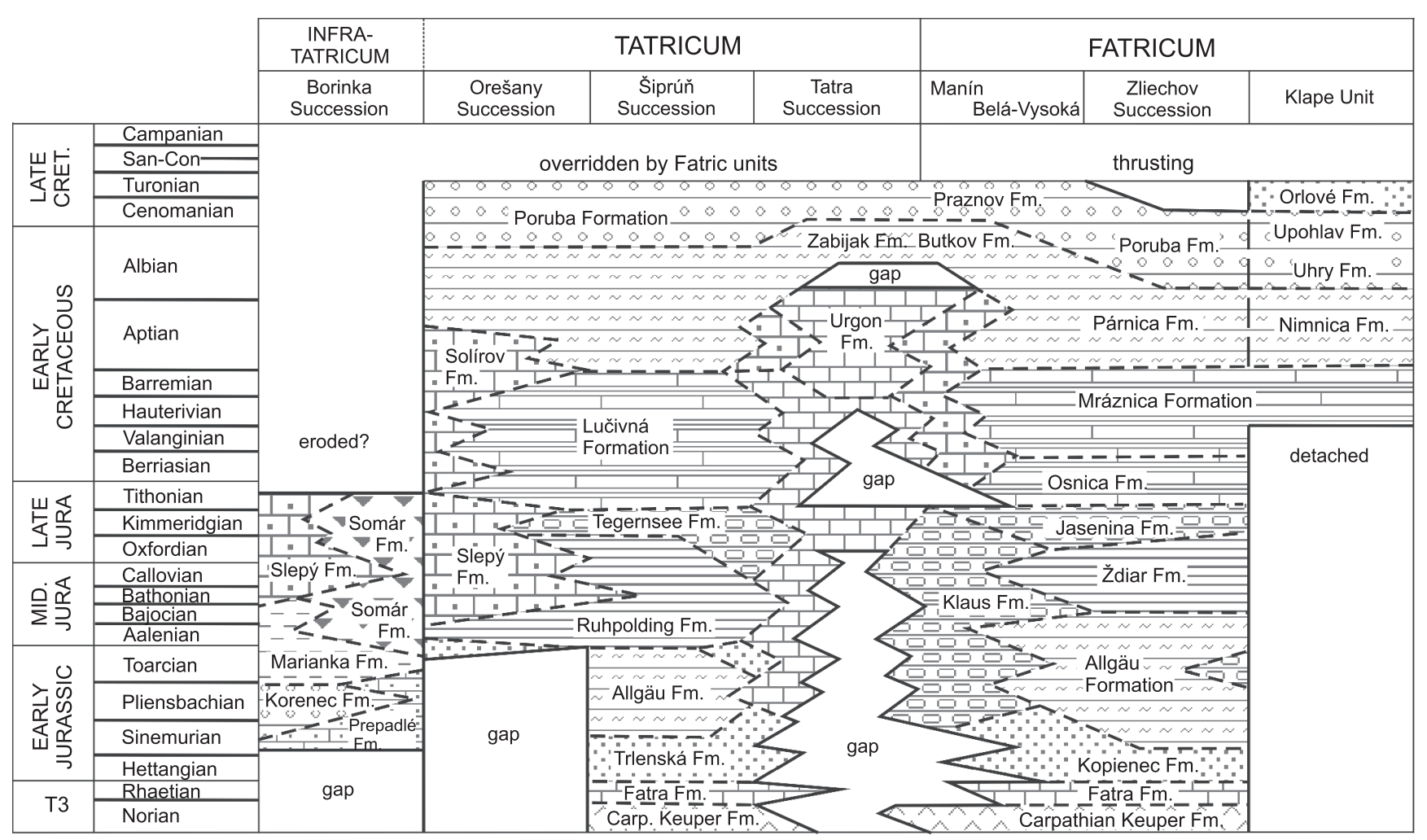

\section{SYN-OROGENIC CLASTICS}

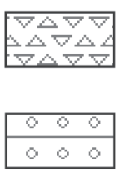

chaotic conglomerates/brecias with olistoliths (upper plate derivation)

turbiditic sandstones, shales and conglomerates (partly exotic)

\section{DEEP-MARINE SEDIMENTS}

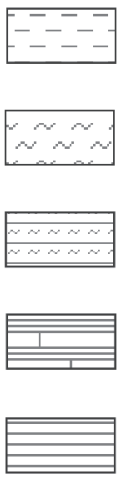

dark and red pelagic shales

variegated pelagic marls

("couches rouges")

dark hemipelagic marlstones,

often spotted ("fleckenmergel")

pelagic limestones, partly with

cherts ("biancone")

radiolarites and siliceous shales

\section{SLOPE AND SWELL DEPOSITS}

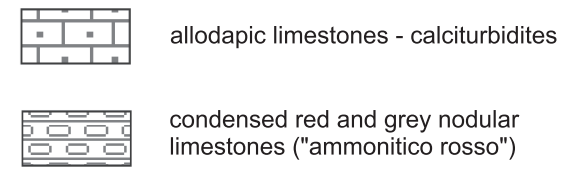

$\square \nabla \begin{aligned} & \text { syn-rift scarp breccias (lower plate } \\ & \text { derivation) }\end{aligned}$

\section{SHALLOW-WATER SEDIMENTS}

shallow-marine and platform
limestones

" mixed siliciclastic and bioclastic syn-rift sediments

continental clastics and evaporites

absent sedimentary record

Fig. 3. Simplified Jurassic-Cretaceous lithostratigraphy of selected Austroalpine/Slovakocarpathian (Tatric and Fatric) successions

hemipelagic dysoxic deposits (fleckenmergel facies, black shales). Considerable change occurred during the Bajocian the Czorsztyn Ridge originated by a strong rifting event, which is characterized by rapid shallowing up to emergence indicated by sudden terrigenous input to form sandy-crinoidal limestones (Fig. 4). The Bathonian stage shows post-rift subsidence and deposition of ammonitico rosso red nodular limestones (Czorsztyn Limestone Formation; e.g., Wierzbowski et al., 1999) until the Tithonian, when shallow marine biogenic sedimentation returned and locally persisted until the Hauterivian.
This oscillation in subsidence was ascribed to several rifting pulses related to the opening and breakup of the South Penninic (Bathonian) and North Penninic (Early Cretaceous) oceanic realms (Plašienka, 2003). Then, the Czorsztyn Succession records emergence and karstification during the Barremian and Aptian (Aubrecht et al., 2006). The final subsidence from the Albian onwards gave rise to red pelagic marlstones of the couches rouges facies (e.g., Mišík, 1994) and terminated by syn-orogenic flysch deposits at the end of the Cretaceous (Fig. 4). On the other hand, the contemporaneous Kysu- 


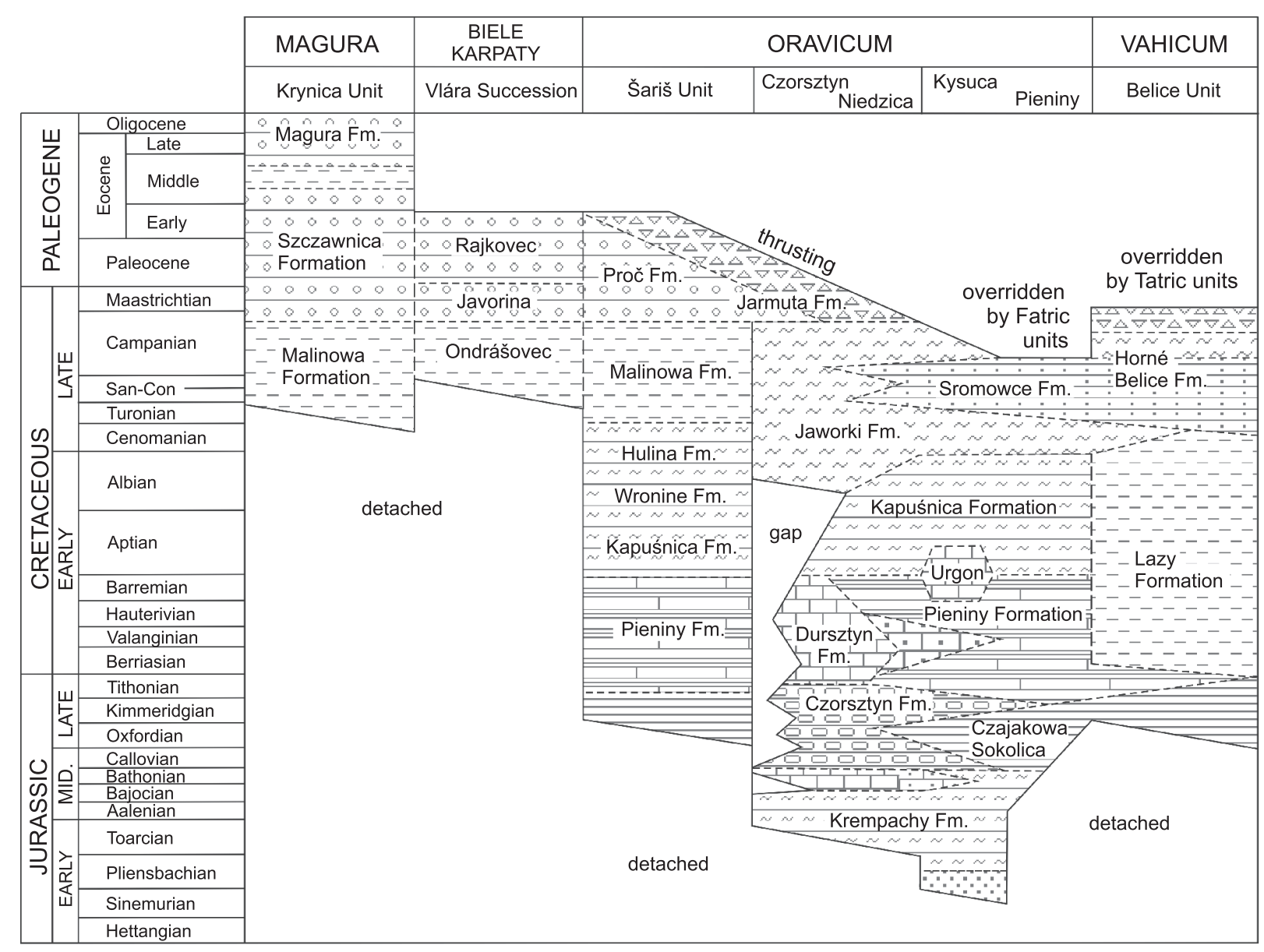

Fig. 4. Jurassic to Paleogene lithostratigraphy of principal Penninic units of the Western Carpathians

$$
\text { For explanations see Figure } 3
$$

ca-Pieniny Succession exhibits continuous deep-marine pelagic sedimentation throughout the Jurassic and Early Cretaceous, which terminates with Late Turonian to Early Campanian flysch clastic deposits with bodies of exotic conglomerate (cf. Marschalko, 1986 and references therein).

The Oravic units are sandwiched between the underlying Magura and Biele Karpaty units (North Penninic) and overridden by the frontal Central Carpathian (Austroalpine) cover nappes (Fatricum - e.g., the Drietoma-Klape and Manín units). The latter originated during the Turonian and were finally emplaced far north beyond the Austroalpine/Piemont (Vahic) passive margin to form a "false" accretionary complex in a South Penninic position (Plašienka, 1995a, b, c), along with their overstepping syn-subduction Senonian to Lower Eocene sedimentary cover (Gosau Group s.l. - Salaj and Began, 1983; Wagreich and Marschalko, 1995; Salaj, 2006).

\section{SYN-RIFT COMPLEXES}

Jurassic (up to Lower Cretaceous in places) coarse-grained clastic sedimentary successions related to opening of the Southern Penninic oceanic domains can be traced all along the northern Austroalpine margin from Eastern Switzerland to western Slovakia. They commonly occur in strongly deformed and variously metamorphosed units, which are generally affiliated to the Lower Austroalpine thrust system and/or to the Upper Penninic nappes (e.g., Tollmann, 1977; Trümpy, 1980, 1988; Schmid et al., 2008; Froitzheim et al., 2008). Consequently, many features of their original sedimentary characteristics have been obliterated and it is often difficult to date these sediments biostratigraphically, as well as to reconstruct the environments and geometry of the sedimentary bodies and the general basin architecture (cf. Ślaczka et al., 2011). Nevertheless, these deposits share numerous mutually common characteristics concerning the composition of the clastic material, types of associated deposit and inferred timing and genetic aspects of their origin.

In the Lower Austroalpine units of the Eastern Alps, Jurassic syn-rift breccias have been described in detail from Eastern Switzerland (the Samedan Zone; Finger, 1978; Trümpy, 1980; Handy, 1996), or the Austrian Tarntaler Berge and Radstädter Tauern Mts. (Tollmann, 1977; Häusler, 1988) at the NW and NE margin of the Penninic Tauern window, respectively (Fig. 1). From the northern frame of the Tauern window, similar breccias were described also from the Upper Penninic nappes, which represent the distal continental margin and/or the peripheral oceanic realm (Prey, 1977; Ślączka et al., 2011). Extraclastic breccias with Triassic carbonate clasts also occur 
in the uppermost Penninic units of the Rechnitz-Köszeg window (Mostler and Pahr, 1981). However, the age and genetic aspects of these breccias are unclear where they were strongly deformed and metamorphosed (cf. Ślączka et al., 2011), in which they might have been mixed with younger syn-orogenic breccias of Upper Cretaceous age. Nevertheless, the Lower Austroalpine successions remained in paraautochthonous position with respect to their basement in places, where they clearly contain material derived from the immediate substratum or from neighbouring complexes. Because of this and of their locally observable basin architecture, these breccias have commonly been interpreted as "scarp breccias" deposited in the vicinity of active extensional faults generated by rifting of the South Penninic Ocean, usually within asymmetrical halfgrabens flanking the passive Austroalpine vs. Penninic margins (Eberli, 1988; Froitzheim and Eberli, 1990).

In the CWC, Jurassic to Lower Cretaceous syn-rift coarse clastic deposits have mostly been described from the Northern Tatric (Infratatric) units of the Malé Karpaty and Považský Inovec Mts. (Fig. 2). The Borinka, Orešany and Devín successions will serve as examples from the former mountains; the latter are represented by the Humienec Succession. Their inferred palaeogeographic relationships are depicted in Figure 5.

\section{BORINKA UNIT}

The southern and central parts of the Malé Karpaty Mts. are built of several superimposed basement/cover allochthonous units affiliated to the Tatric superunit (Plašienka et al., 1991). The lowermost structural position of this Tatric Nappe stack is occupied by the Borinka Unit. It crops out on the NW slopes of the Malé Karpaty Mts. (Fig. 2), in a tectonic half-window from below the large, basement-involved Bratislava Nappe . It forms the largest "blue spot" to be seen on general geological maps of the Slovakian Western Carpathians, which suggests a significant amount of Jurassic strata present there (altogether more than $1 \mathrm{~km}$ thick), in contrast to the other parts of the Western Carpathians.

The sedimentary infill of the Jurassic Borinka Basin exhibits a noticeably asymmetrical arrangement of proximal and distal deposits that are composed mostly of terrigenous clastic deposits

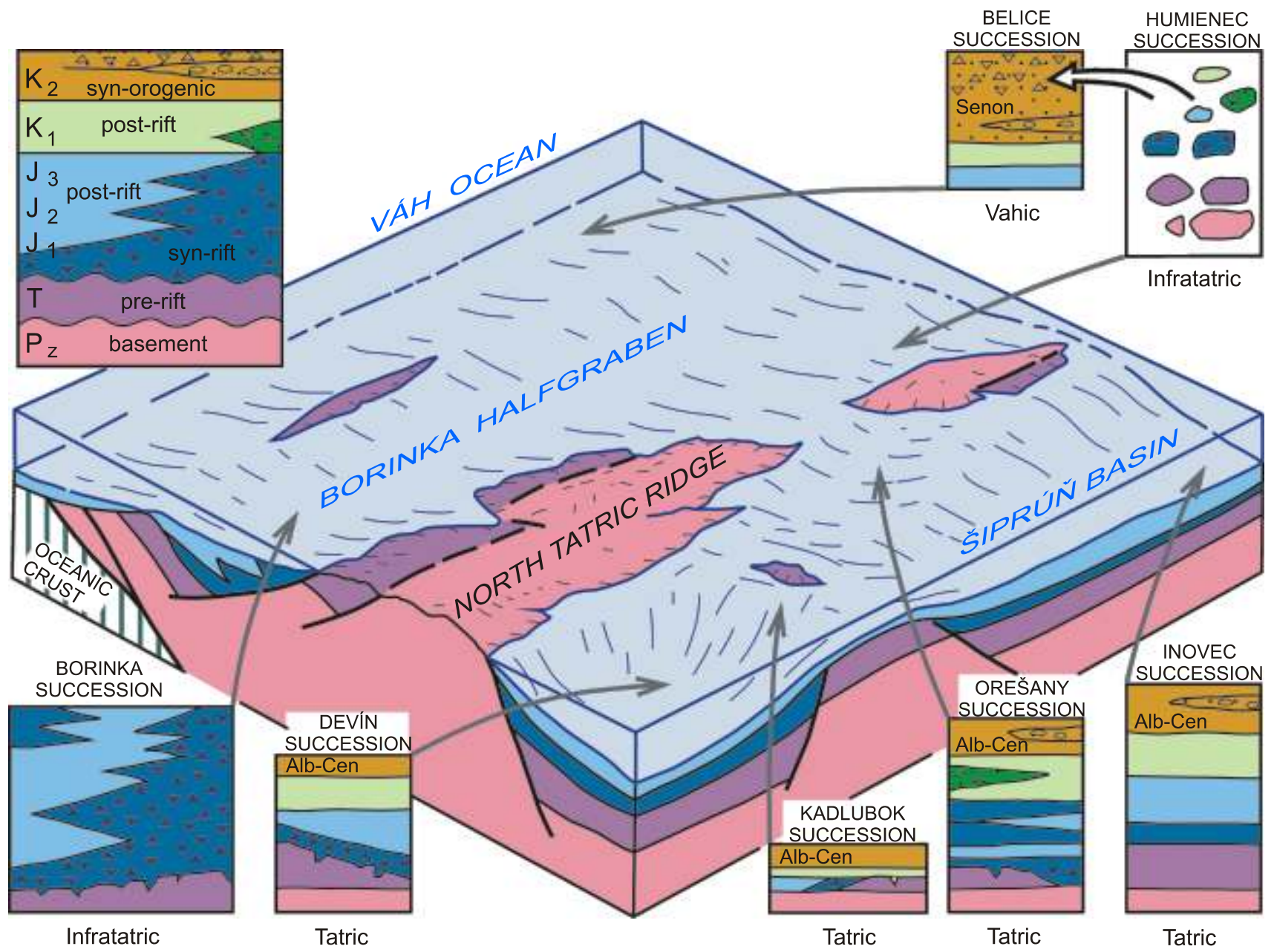

Fig. 5. Block diagram illustrating the palaegeographic relationships of lithostratigraphic successions positioned along the northern Tatric continental margin facing the Váh Ocean to the NW and the Tatric Šiprún Basin to the SE (in present coordinates); approximately the Late Jurassic situation 
(Fig. 3). During the mid-Early Jurassic (Sinemurian-Pliensbachian), massive limestones (Ballenstein Limestone Member) showing evidence of redeposition, olistostromatic bodies of extraclastic carbonate breccias and giant olistoliths of Triassic carbonate (Fig. 6A-C), as well as bioclastic limestones and quartzitic sandstones (Prepadlé Formation, at least 300 m thick) were deposited in the SE marginal position (Plašienka, 1987; Plašienka in Polák, 2012). Simultaneously, the central and NW parts of the basin were filled with mixed carbonate-siliciclastic turbidites and hemipelagic spotted marlstones (Korenec Fm., up to $800 \mathrm{~m}$ thick). The terrigenous input ceased in the axial part of the halfgraben by the Late Lias, when anoxic black shales were laid down (Toarcian-Bathonian? Marianka Formation, more than $300 \mathrm{~m}$ thick; Fig. 6F). The partly coeval and overlying Slepý Formation (Middle-Upper Jurassic, more than $200 \mathrm{~m}$ thick) consists of calciturbidites containing shallow-water biodetritus (Fig. 6G). Contemporaneously with the Marianka and Slepý formations, huge masses of coarse-grained scarp breccias (Somár Fm., some 500 m thick; Fig. 6E) accumulated in the proximal SE part of the basin, just above the Prepadlé Formation. The clastic material of the Somár mixtitic breccias is dominated by basement rocks (Paleozoic phyllites, amphibolites and granites) with numerous olistoliths of Triassic quartzite and carbonate. The marginal parts of breccia aprons are clast-supported and locally totally matrix-free, while more distal, frontal parts of breccia bodies reaching the halfgraben axis are lime mud-supported and occasionally diluted to high-density turbidity current deposits. These proximal disorganized sediments were deposited as debris avalanches and mass-flows derived from fault-controlled linear sources located to the SE, while the Korenec turbidites were most probably fed by a river that drained a wide dry land (see the model reconstruction in Fig. 7). By contrast, calciturbidites occurring in the Marianka and Slepý formations are almost free of siliciclastic material and were likely derived from the gentler NW counter slope of the basin. Based on these features, the Borinka Basin is reconstructed as an elongated tilted halfgraben some $10-15 \mathrm{~km}$ wide with a steep, normal-fault escarpment on its SE side. This Early to Middle Jurassic fault separated the basin from a continental ridge (North Tatric Ridge; Plašienka, 1995a), which was temporarily exposed to subaerial erosion. During Late Cretaceous shortening, the Borinka Unit was overthrust by the Tatric Bratislava basement nappe, thus the source ridge was hidden below and does not crop out at the surface at present. The overthrust plane is accompanied by a ductile shear zone with top-to-the-NW kinematic indicators (Plašienka, 1990; Fig. 6D, E).

By its immense thickness and dominance of unsorted, coarse-grained, deep-marine clastic deposits, the Jurassic Borinka Succession has no equivalents in the entire Carpathians. However, its close analogies can be found in cover successions of the Lower Austroalpine nappes of the Eastern Alps, where similar Jurassic scarp breccias are interpreted as derived from marginal normal faults that flanked the opening South Penninic Ocean to the S (see Häusler, 1988; Häusler et al., 1993; Ślączka et al., 2011 and references therein). Such a position fits well also the Carpathian situation, despite no undisputable Penninic oceanic elements being found at the surface. The long (some $30 \mathrm{Ma}$ ), though episodic, activity of the SE marginal fault of the Borinka halfgraben allows for its interpreta- tion as a master break-away fault that separated the lower (SE) and upper (NW) plates of an asymmetrical rift zone, which was active until the final break-up of the South Penninic oceanic tract that occurred further to the NW in the late Middle Jurassic (Plašienka, 2003).

\section{DEVÍN SUCCESSION}

The Devín Succession is exposed at the western extremity of the Carpathians near Bratislava. It forms the sedimentary cover of the Tatric Bratislava Nappe front, which overthrusts the Borinka Unit. It contains pre-rift Upper Permian and Lower Triassic clastics and Middle Triassic carbonates. The uneven erosional, possibly also karstified surface of the latter is covered by upper Lower-lower Middle Jurassic carbonate breccias (the Pleš Breccia; Michalík et al., 1993; Michalík and Vlčko, 2011) containing local material derived from the underlying carbonates. The breccias are mostly supported by the limy matrix that fills also Neptunian dykes in the Triassic substratum. In places, in situ break-apart of lithified Triassic carbonate fragments injected by unconsolidated Jurassic lime mud can be observed (Fig. 6H). We infer that these structures resulted from rifting-related seismic events on a subsiding carbonate shelf. The unstable shelf edges might have eventually collapsed to form rock slides and debris flows that transported coarse carbonate clastic material to adjacent normal fault-controlled basins of the Borinka halfgraben type (Fig. 5).

Other Mesozoic cover successions of the Bratislava Nappe are present in a small area, indicating abrupt lateral facial changes due to the rugged syn-rift morphology of the area (Fig. 5). The Kuchyňa Succession is characterized by deep syn-rift denudation and deposition of Middle Jurassic strata directly on the pre-Alpine crystalline basement followed by a rapid deepening. However, numerous allodapic clastic limestones indicate the proximal position of the Kuchyňa Basin (Plašienka et al., 1991; Michalík et al., 1993) with respect to the adjacent Kadlubok Succession deposited on a submarine high. This is characterized by the extremely condensed Jurassic-Lower Cretaceous succession with numerous hiatuses, Neptunian dykes and syn-sedimentary breccias (Michalík et al., 1994).

\section{OREŠANY UNIT}

Another Tatric cover succession, the Orešany Unit, subautochthonous with respect to the Bratislava Nappe, is exposed in the NE part of the Male Karpaty Mts. (Fig. 2). It also shows deep erosion of pre-rift strata and rapid Middle Jurassic subsidence with an up to $300 \mathrm{~m}$ thick calcarenite sequence deposited in three coarsening-upwards cycles (Slepý Fm.; Plašienka et al., 1991; Fig. 3). Numerous allodaps occurred here also during the Late Jurassic and Early Cretaceous. The Barremian-Aptian Solírov Fm. is of special importance, since it contains resedimented allodapic sandy-crinoidal limestones and olistostrome bodies carrying olistoliths several metres across of pre-rift complex rocks (Jablonský et al., 1993). Sudden input of terrigenous material at this time indicates either renewed rifting, or the first signs of contraction along the northern Tatric margin (Solírov Phase - see below). 

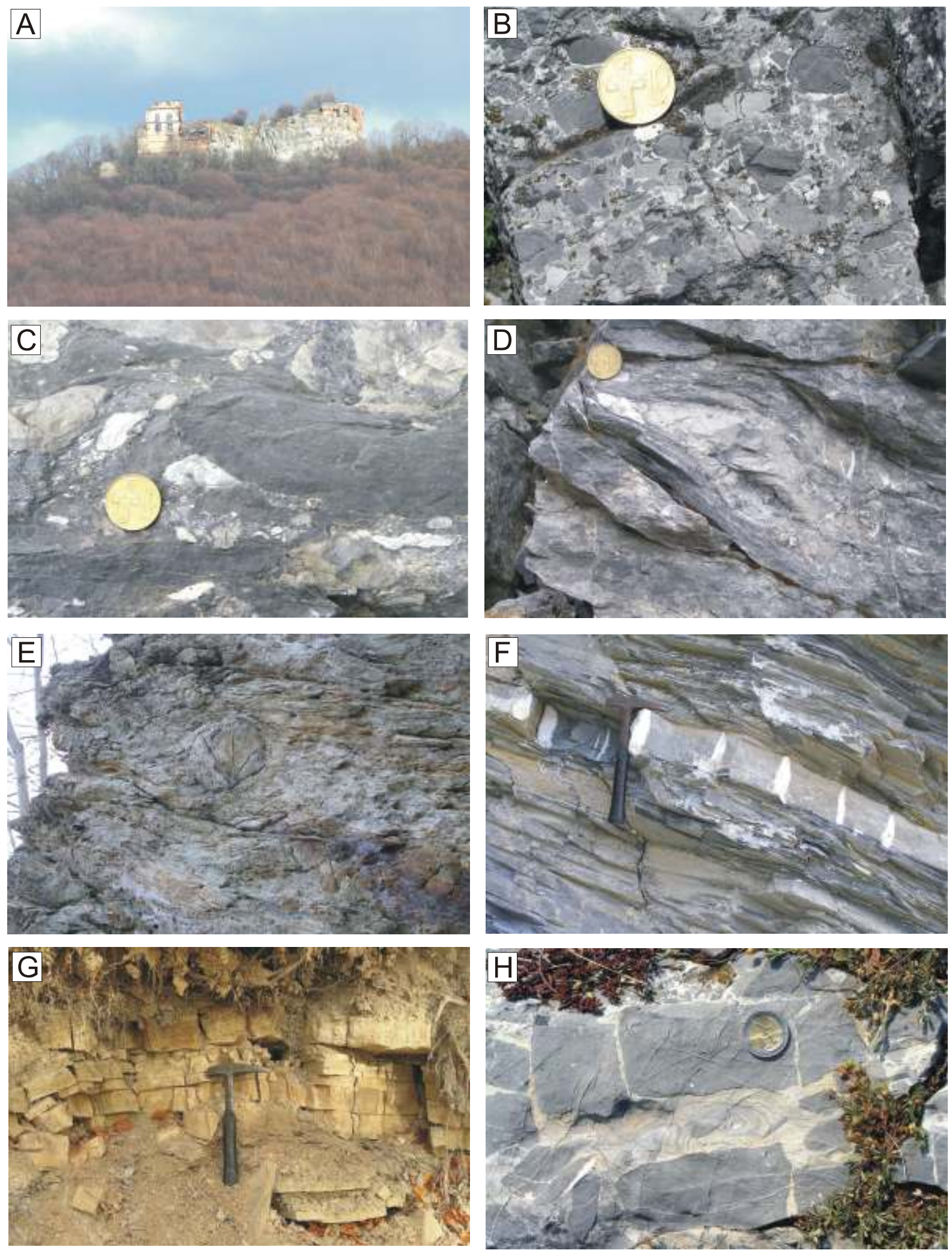

Fig. 6. Photo-table of syn-rift sediments of the Borinka (photos A-G) and Devín (photo H) successions (Malé Karpaty Mts.)

A - mega-olistolith of Triassic carbonates with ruins of the Pajštún castle above the Borinka village; B - Lower Jurassic extraclastic clast-supported carbonate breccias, the host rock of the Pajštún olistolith; $\mathbf{C}$ - matrix-supported extraclastic carbonate breccias, Prepadlé Valley near Borinka; $\mathbf{D}$ - deformed $\sigma$-clast of Triassic dolomite indicating top-to-the-NW thrust direction of the Tatric Bratislava Nappe overriding the Borinka Unit, the same locality as photo $\mathrm{C} ; \mathbf{E}$ - polymictic clast-supported breccias of the Somár Fm. (Middle Jurassic of the Borinka Unit), the rounded clast in the centre is a more resistant amphibolite fragment surrounded by strongly sheared phyllite clastic material forming a "pseudomatrix", Prepadlé Valley; F - black calcareous shales with a calciturbidite bed, Marianka Fm. (Toarcian) of the Borinka Unit, former quarry for roofing slates in Marianka village; $\mathbf{G}$ - calcarenites of the Slepý Fm. (Middle-Upper Jurassic of the Borinka Unit), Turecký vrch military area; $\mathbf{H}$ - in situ fragmentation of the Triassic carbonate substratum with fissures injected by Jurassic lime mud, Devín Succession of the Tatric Bratislava Nappe, Devínska Kobyla Hill near Bratislava 


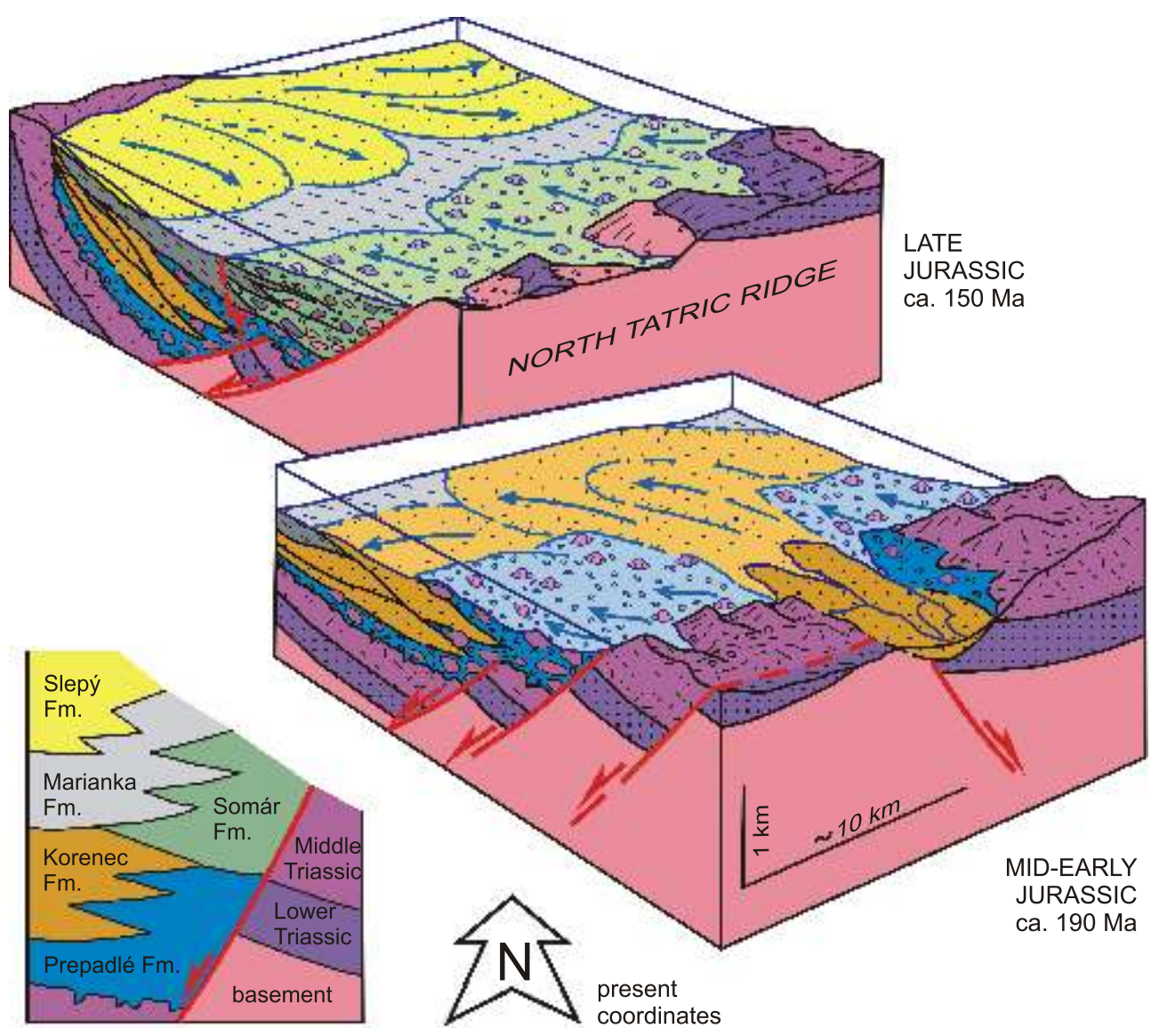

Fig. 7. Model of two evolutionary stages of the Borinka halfgraben

The Early Jurassic situation reflects the symmetric rifting mode (Zliechov Phase), the Late Jurassic halfgraben tilting occurred during asymmetric rifting and breakup of the Vahic oceanic zone to the NW (Krasín Phase)

\section{HUMIENEC SUCCESSION}

In the Považský Inovec Mts., the outermost Tatric margin is represented by the compound Humienec Succession. Its composition is reconstructed from secondary occurrences only, since it does not occur at the present-day surface. Fragments up to the mega-olistolith size occur in the Senonian breccias of the Belice Unit (Fig. 8). In addition to olistoliths of basement micaschist, Permian to Lower Triassic clastic rocks and Middle Triassic carbonates, the breccias contain blocks of Lower to Middle Jurassic biodetrital limestone with substantial terrigenous, psamitic to psephitic siliciclastic admixture (Plašienka et al., 1994; see also Putiš et al., 2006, 2008). Olistoliths of Calpionella limestones with angular fragments of basement micaschists are unique to the area. Altogether, the Humienec Succession indicates deposition in an extensional tectonic setting in the vicinity of a long-term active fault escarpment.

In general, the Tatric and Fatric successions located internally of the northern Tatric margin exhibit a generally uniform evolution with one principal rifting event during the earliest Jurassic followed by continuous, but fading post-rift subsidence until the beginning of the Late Cretaceous. The Tatric-Fatric sedimentary area consists of two wide basinal domains - the Tatric Šiprún Basin and the Fatric Zliechov Basin, separated by the South Tatric Ridge, represented for instance by the High
Tatra swell-type successions (e.g., Lefeld et al., 1985; Wieczorek, 2000; Figs. 3 and 5). Distribution of marginal and slope facies within the Zliechov Basin has been interpreted in terms of transtensional, pull-apart opening (Michalík, 2007). Its partial inversion started during the Aptian, but coarseningand thickening-upwards syn-orogenic sedimentation commenced later during the Albian and persisted for some $10 \mathrm{Ma}$ until the Cenomanian (Fig. 3). Deep-marine terrigenous clastic deposits (Poruba Fm.) typically contain bodies of exotics-bearing conglomerates (Mišík et al., 1981). During the Turonian, the attenuated continental crust of the Zliechov Basin was underthrust below the Veporic basement sheet prograding from the hinterland, the Zliechov and other Fatric sedimentary successions were detached and thrust over the foreland Tatric areas as the Krížna and related cover nappes (Prokešová et al., 2012 and references therein).

\section{CZORSZTYN SUCCESSION}

In contrast to the CWC units, the Jurassic to Cretaceous sedimentary successions deposited on the Oravic-Czorsztyn Ridge and in its proximity record a complex subsidence history (Plašienka, 2003). The comparatively deep-water Liassic-Aalenian sequence was replaced by extremely shallow-wa- 

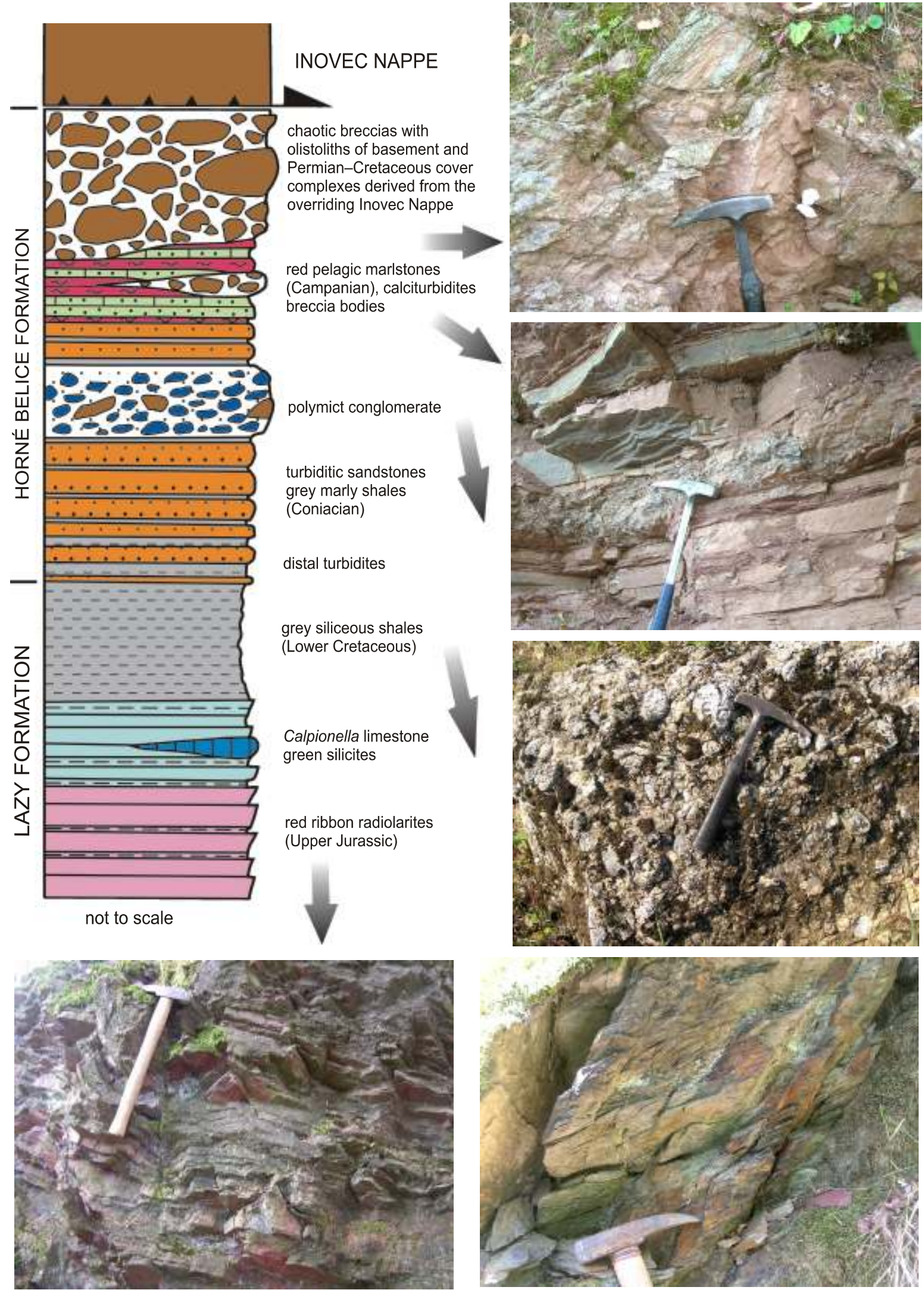

Fig. 8. Lithostratigraphic column and field photos of representative formations of the Belice Unit, Považský Inovec Mts. 
ter crinoidal and sandy limestones during the Bajocian (Aubrecht and Sýkora, 1998; Fig. 4). By the end of the Bajocian, these sandbanks collapsed and experienced Late Jurassic subsidence to bathyal depths. However, parts of the Czorsztyn Ridge remained in a very shallow position, indicated by the presence of Upper Jurassic platform limestones (Mišík, 1979; however, presently this reefal facies has been reinterpreted by Schlögl et al., 2009, as being most probably of Bajocian age). The Middle Jurassic elevation of the Czorsztyn Ridge is indicated by remarkable shallowing and development of syn-sedimentary breccias (Krasín Breccia; Mišík et al., 1994a; Aubrecht et al., 1997; Aubrecht and Szulc, 2006; Krobicki, 2009). The breccias are composed of only slightly older material of sandycrinoidal limestone and were interpreted as scarp breccias deposited at the feet of active normal fault escarpments. They bear signs of freshwater cementation pointing to emergence of parts of the ridge above the sea level (Aubrecht et al., 1997), along with siliciclastic terrigenous admixture. Coeval, allodapic crinoidal limestones (Samášky Fm., Aubrecht and Ožvoldová, 1994) were deposited in slope environments (Niedzica/Pruské Succession; Fig. 4).

During the Early Cretaceous, the ridge was elevated again, as indicated by shallow-water deposits and signs of emergence. This second uplift event of the Czorsztyn Ridge is manifested through shallowing of sedimentary successions, syn-rift debris flow deposits and carbonate scarp breccias (Walentowa Breccia; Birkenmajer, 1977; Krobicki et al., 2010). The uplift culminated with emergence, karstification, erosion and non-deposition during the Barremian and Aptian (Aubrecht et al., 2006). Simultaneously, the allodapic Horná Lysá Limestone and Hauterivian turbidites accumulated in the basinal Kysuca Succession (Mišík et al., 1994b; Aubrecht, 1994). The peculiar Nižná Succession occurring in the Orava sector of the PKB has lithostratigraphic units mostly similar to the Kysuca Succession, but it contains also Urgon-type platform limestones (Nižná Limestone; Scheibner, 1967) underlain by erosional breccias (Tvrdošín Breccia Member; Józsa and Aubrecht, 2008; Fig. 4).

\section{RIFTING PHASES}

The series of rifting stages related to opening of the Penninic oceans in the Carpathians has been interpreted by Plašienka (2003) - cf. Figure 13. The oldest, Early Jurassic Zliechov Phase ("Palaeo-Kimmerian") affected extensive areas of the northern passive margin of Tethys, i.e. all future Austroalpine-Slovakocarpathian and Penninic areas. In place of a rather uniform Triassic carbonate platform a new system of basins and ridges developed. Rifting created wide Jurassic basinal areas (Magura, Kysuca-Pieniny, Šiprúň, Zliechov) and narrow intra-basinal swells (North Tatric and South Tatric ridges; Fig. 5). The basinal successions retained complete and mostly undisturbed pre-rift sequences followed by only thin Lower Liassic, syn-rift terrigenous marine clastic deposits. These basins were already subsiding during Early Jurassic times and quickly acquired hemipelagic and, during the Middle-Late Jurassic, eupelagic deposits that accumulated partly below the CCD (radiolarites). The large areal extent indicates that this initial rifting was of the symmetric "wide rift" type (e.g., Buck, 1991), generated by nearly homogeneous lithospheric stretching and crustal thinning.

The initial rifting phase was followed by the weaker upper Liassic Devín Phase, during which additional crustal attenuation and extensional block tilting occurred. Normal fault activity and deep erosion of uplifted footwall blocks occurred around the North Tatric Ridge area in particular (Fig. 7). It is noteworthy that the prominent Czorsztyn Ridge did not yet exist, and the Czorsztyn domain was part of a wide basinal area including the neighbouring Kysuca-Pieniny and Magura basins.

The Middle Jurassic rifting of the Krasín Phase ("MesoKimmerian") took place in a more restricted area around the future break-up zone of the South Penninic-Vahic Ocean. An asymmetrical rifting mode is indicated by the contrasting subsidence histories of the margins of the rift zone (Plašienka, 2003). The lower, Slovakocarpathian (Tatric) plate margin acquired a narrow rift shoulder and the break-away system of tilted halfgrabens was filled with thick aprons of scarp breccia (Fig. 7), while the distal, broad upper-plate margin (Czorsztyn Ridge) was elevated during the Early Bajocian (e.g., Krobicki and Wierzbowski, 2004; Krobicki, 2009; Schlögl et al., 2009; Fig. 4). The subsequent latest Bajocian hiatus on the Czorsztyn Ridge corresponds to an oceanic break-up discordance followed by a pronounced thermal subsidence stage during the Bathonian-Late Jurassic.

The Czorsztyn Succession records a second, distinct uplift event during the Early Cretaceous, named the Walentowa Phase (corresponding to "Neo-Kimmerian" movements). This was interpreted as a consequence of an additional phase of asymmetrical lithospheric rifting, which ultimately led to the opening of the Magura Ocean on the northern side of the Czorsztyn Ridge (Plašienka, 2003). The ridge preserved its upper plate position; therefore it again experienced syn-rift thermal uplift. Following the model of a passive margin affected by several extensional detachment systems (Lister et al., 1986), the Czorsztyn Ridge is interpreted as a marginal plateau or ribbon continent. However, lowermost Cretaceous stratiform breccia bodies occur also in various Central Carpathian units, e.g. in the Humienec Succession mentioned above or in the Fatric Krížna Nappe (Nozdrovice Breccia; Michalík et al., 1996), which points to the large extent of this rifting phase.

The above-characterized extensional tectonic phases were followed by an additional distinct tectonic event during the Barremian-Early Albian, designated the Solírov Phase. This is indicated by the growth of the Urgonian carbonate platform on the former South Tatric Ridge and in restricted Oravic areas (Nižná Succession), by tectonically driven resedimentation events around the North Tatric Ridge (calciturbiditic Solírov Fm.), and by the uplift, erosion and karstification of the Oravic Czorsztyn Ridge, as well as by restricted alkaline basaltic volcanism (Figs. 3 and 4; cf. Fig. 13).

A sequence of rifting events equivalent to that described above was reconstructed for large areas of the European, Austroalpine and South Alpine shelves of the Alpine Tethys/Atlantic (e.g., Lemoine et al., 1986; Froitzheim and Eberli, 1990; Bernoulli et al., 1993; Froitzheim and Manatschal, 1996; Claudel and Dumont, 1999). Liassic symmetrical rifting was succeeded by Middle Jurassic simple shear extension and break-up of the Ligurian-Piemont Ocean, which pro- 
duced also thermal uplift of the broad, upper plate Briançonnais rift shoulder. Finally, the separation of the Briançonnais ribbon continent from the European margin and break-up of the North Penninic (Valais) Ocean occurred probably in the Early Cretaceous (Frisch, 1979; Florineth and Froitzheim, 1994; Stampfli, 1994). Opening of both the South and North Penninic oceanic branches was ascribed to the eastwards propagation of the Central Atlantic and the North Atlantic and Bay of Biscay rift systems, respectively (Frisch, 1981; Lemoine and Trümpy, 1987; Stampfli, 1994, 1996). The Cretaceous North Penninic rift system (Valais Ocean) partly re-rifted the Jurassic South Penninic Ocean (Liati et al., 2005).

Rifting of the Penninic oceans was essentially non-volcanic. For instance, Manatschal and Bernoulli (1999) and Manatschal and Münterer (2009) characterized the magmapoor ocean/continent transition of this type as a complex association of subcontinental mantle exhumed along low-angle detachment faults, fragments of continental basement (extensional allochthons), tectono-sedimentary breccias, post-rift deposits and various basic volcanic rocks ranging from MORB-type to alkaline. Evolution of such margins progressed from a non-volcanic asymmetrical rifting stage to breakup accompanied and followed by mafic magmatism. Alkaline magmas were emplaced later during a post-breakup stage.

This scheme applies also for the Carpathians, despite true ophiolites not being exposed at the surface. According to Spišiak et al. (2011 and references therein), the alkaline basaltic volcanism was widespread in time and space, though volumetrically restricted to submarine lavas, mostly hyalobasanites, and dykes or small sills. This volcanism was initiated during the Berriasian around 145-140 Ma ago (new data by Reháková et al., 2011; Madzin et al., 2011) and occurred throughout the Cretaceous with the main phase clustering at around 125-100 Ma, i.e. during the Aptian to Albian. The small amounts of effusive volcanic material, low degree of its differentiation and crustal contamination, as well as the primitive geochemical characteristics point rather a rapid ascent of tiny portions of mantle melts that pierced an overlying lithosphere attenuated by preceding and coeval rifting events. The alkaline basaltic volcanism occurred on passive continental margins of the Penninic rifts (distal European Silesian margin, Oravic Czorsztyn continental ribbon, extended Austroalpine margin) and generally postdated the main rifting phases, hence it appears to be the product, not the cause, of rifting (Spišiak et al., 2011).

\section{SYN-OROGENIC SUCCESSIONS}

Syn-orogenic clastic sedimentary successions related to compressional tectonic regimes terminate sedimentation in the successions of inverted basins. In the course of ongoing deformation, they were often destroyed shortly after origin and their material can be recycled several times. Syn-orogenic breccias/conglomerates are very variable in their composition and genesis and contain detrital material derived either from wide orogenic zones characterized by a complex geological structure, or from destroyed fronts of local thrust sheets.

\section{BELICE UNIT}

During the Late Jurassic and Cretaceous, the northern Tatric (Infratatric) margin faced the South Penninic oceanic realm named the Váh Ocean in the Carpathians (Mahel', 1981). Originally, Mahel' assigned, to his Vahicum, first of all the thick prisms of "exotic" conglomerate of the Klape Unit in the Middle Váh Valley. However, it was inferred later by Plašienka et al. (1994, 1995) and Plašienka (1995a, b, c, 1999) that the Belice Unit of the Považský Inovec Mts. represents the only definable Vahic element in the present surface structure of the Carpathians. The Belice Unit crops out in the northern and southernmost part of the Považský Inovec Mts., thanks to an antiformal thrust stack and extensional exhumation during Miocene formation of the Danube Basin, respectively.

The Belice Unit is composed of two main formations (Figs. 4 and 8). The Lazy Formation (Plašienka et al., 1994) is several tens of metres thick, comprising a strongly imbricated eupelagic succession of red, well-bedded Oxfordian-Tithonian radiolarite and greenish silicite with scarce intercalations of white Calpionella-bearing limestone, and dark grey siliceous slate of Early Cretaceous, up to Aptian-Albian age (closely resembling the Ligurian "Palombini shales" of the Western Alps and Apennines). There occur also Turonian variegated marlstones of couches-rouges type (see also Putiš et al., 2006, 2008).

The Horné Belice Formation is a Senonian sequence of deep-marine flysch clastics deposits hundreds of metres thick. The lower, Coniacian-Santonian part consists of thinly bedded distal calcareous turbidites and thick-bedded sandstones with lenses of polymictic conglomerate deposited in the middle and outer parts of the submarine turbidite fan (Plašienka et al., 1994). Two main types of pebbles have been observed in the conglomerates, not including intraclasts. Over $90 \%$ of the pebble material is formed of well-rounded, almost exclusively carbonate clasts - Middle Triassic dolomites and limestones, Upper Triassic lagoonal limestones, limestones of the Fatra (Kössen) Formation, Liassic bioclastic limestones, Upper Jurassic and Lower Cretaceous pelagic limestones, Urgonian limestones and rare pebbles of volcanic rock and granitoid (Fig. 8). The second group includes scarce larger, angular fragments of rock clearly derived from the overriding Inovec Nappe: mica-schists, Permoscythian clastic rocks and Liassic sandy crinoidal limestones. Large angular clasts of green amygdaloidal basalt may represent a third type of source area.

The upper, Campanian to possibly Lower Maastrichtian, sequence comprises purple-red marly shales, greenish-grey calcareous sandstones and olistolith-bearing chaotic breccia bodies composed dominantly of material of the overlying Infratatric Inovec Nappe - basement mica-schists, fragments of Permoscythian clastic rocks, blocks and olistoliths of Triassic carbonate, Jurassic sandy biodetritic or nodular limestones and Lower Cretaceous pelagic limestones with mica-schist fragments (Humienec Succession, see above; Fig. 8). These deposits represent typical proximal turbidites with breccia debris flows deposited along a slope hinge (Marschalko in Plašienka et al., 1994). There are also clasts, olistoliths and tectonic slices formed of mafic volcanic rocks - within-plate amygdaloidal basalts (cf. Soták et al., 1993b) - which were possibly derived from a destroyed seamount of the subducted Vahic oceanic crust. Another 
interpretation suggest a Permian age for them and derivation from the Inovec Nappe (Putiš et al., 2006, 2008).

It is supposed that the Belice Succession is a detached sedimentary cover of the Vahic (South Penninic) oceanic crust that was subducted southwards beneath the northern Tatric edge. Alternatively, it was deposited on a distal passive continental margin (Putiš et al., 2006, 2008). However, geochemical patterns in the red pelagic shales associated with Upper Jurassic ribbon radiolarites indicate their origin by decomposition of basaltic protolith and thus their deposition in the proximity of a mid-oceanic ridge is inferred.

The onset of shortening of the Belice Basin and subduction of the Vahic lithosphere was heralded by start of flysch sedimentation during the Coniacian. Senonian clastic rocks of the Horné Belice Formation were deposited in a trench basin in front of the convergent Tatric margin and were later scraped off their underthrust substratum and piled up in an accretionary complex. The convergence setting is also indicated by the increasing share of clastic material in coarse-grained strata, material which was undoubtedly derived from the Tatric complexes of the Inovec Nappe presently tectonically overlying the Belice Unit (Fig. 9).

In general, the Belice Unit records a sedimentary gradation from Upper Jurassic abyssal pelagic deposits up to coarsening-upwards Upper Cretaceous syn-orogenic clastics. In this respect, it has no surface analogues in the Western Carpathians. By their chaotic nature and presence of olistoliths of various provenance, including rock of the Austroalpine (Infratatric) margin, the Senonian strata of the Belice Unit are similar to the olistostrome/mélange units occurring in zones around the Upper Penninic-Austroalpine boundary in the Eastern Alps. These zones include e.g., the Platta Nappe and Arosa Zone (Dietrich, 1970; Weissert and Bernoulli, 1985), the "Tauern Flysch" and Matrei Zone (Frisch et al., 1987), part of the Klammkalkzone (Ślączka et al., 2011), or the Ybbsitz Klippen Belt (Decker, 1990; Homayoun and Faupl, 1992; Schnabel, 1992). Hence, although the Penninic-Vahic affiliation of the Belice Unit and the presence of any such elements in the Carpathians were questioned by some authors (Rakús and Hók, 2005; Ivanička and Kohút, 2011), we still regard prolongation of the South Penninic oceanic zone into the Carpathians as inevitable for geodynamic reasons. Concurrently we believe that the sedimentary record of both the Middle Jurassic syn-rift clastic deposits and Upper Cretaceous syn-orogenic complexes in zones along the CWC-PKB contact zones provide indirect positive evidence for the existence of such an ancient oceanic tract.

\section{KLAPE UNIT}

In the western part of the PKB, in the Middle Váh Valley (Púchov sector; Fig. 2), the Klape Unit - a large and puzzling

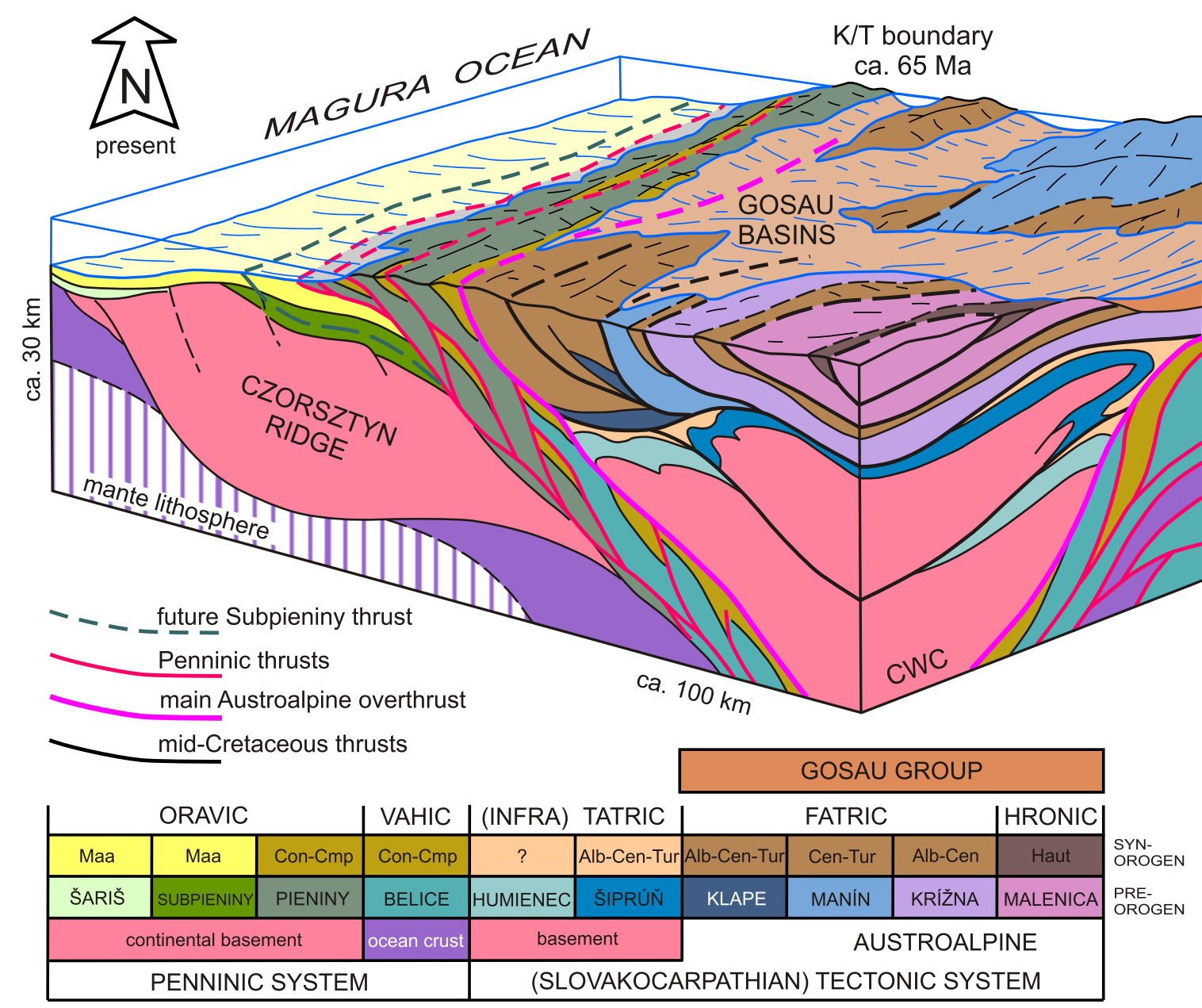

Fig. 9. Tentative reconstruction of the convergence zone between the Central Western Carpathian (Austroalpine) frontal units and the Oravic domain during the latest Cretaceous in western Slovakia 
PKB element - crops out. At present, it is positioned between the overriding Manín Unit and underlying Oravic units of the "Klippen Belt sensu stricto" (Fig. 9). The Klape Unit is composed of prisms some thousand metres thick of mostly proximal flysch to wildflysch successions, including chaotic boulder beds and mega-olistoliths (Marschalko, 1986). Owing to its position along the inner PKB side (the so-called Periklippen Zone), Mahel' (1980, 1981) considered the "Klape Flysch" as the main element of his Vahicum. Accordingly, the Klape Flysch should represent an element of the South Penninic accretionary complexes of even larger dimensions than those occurring in the Alps. However, this interpretation is not consistent with the age and composition of "exotic" conglomerates, which are the most conspicuous element of the Klape Unit (cf. Plašienka, 1995a, b).

The exotic, so-called Upohlav conglomerates (Andrusov, 1938) occur at two stratigraphic levels: Albian-Lower Cenomanian and Coniacian-Santonian, and are separated by the Upper Cenomanian-Turonian shallowing-upwards sequence of massive sandstones with tempestites and oyster banks (Orlové Fm.; Fig. 3). The conglomerates have an exceptionally variegated composition with numerous rock types (Fig. 10A, B), which were studied and described in detail by Mišík et al. (1977, 1991), Mišík and Sýkora (1981), Marschalko (1986), Mišík and Marschalko (1988), Birkenmajer (1988), Birkenmajer et al. (1990), Faryad and Schreyer (1996) and Mišík and Reháková (2004). Besides many common rock types, the most noticeable exotic material comprises basinal Triassic limestones, Upper Jurassic platform limestones, Urgonian limestones with serpentinite clasts, Permian A-type granites with Lower Cretaceous FT cooling ages (Uher and Pushkarev, 1994; Kissová et al., 2005), large amounts of basaltic and calc-alkaline volcanics of uncertain age (Permian, Late Jurassic?), Upper Jurassic glaucophanites (Dal Piaz et al., 1995), prevailing Cr-spinels in heavy mineral spectra (Jablonský et al., 2001) and so on. To explain the source of these exotic clasts, which do not occur in primary position in the PKB and neighbouring zones at all, the concept of a temporary Cretaceous "exotic ridge", "Klape ridge", "Pieniny (ultra-Pieninic) cordillera", or "Andrusov ridge" was developed decades ago (e.g., Birkenmajer, 1988).

With the advent of the plate tectonic theory, this exotic ridge has been interpreted as a compressional tectonic structure in an active margin setting - imbricated slices of obducted oceanic material or subduction mélange temporarily outcropping along the outer structural high of an accretionary palaeoprism (Mišík, 1979), a subduction complex exhumed in the rear part of the South Penninic-Vahic accretionary wedge (Mahel', 1989), or a magmatic island arc (Birkenmajer, 1988). Exotic pebble material would indicate Triassic opening of the corresponding oceanic basin and its Late Jurassic-Early Cretaceous closing (e.g., Birkenmajer, 1988; his "Ocean X"; Dal Piaz et al., 1995). However, this concept is inconsistent with the geological record of all other PKB and neighbouring units, where no such events can be documented or even indicated. On the other hand, these events surely occurred in the southern Western Carpathian zones, where they were associated with the opening and closing of the Neotethyan Meliata Ocean.
However, the problem remained as how this material could have been transported through wide CWC zones with rugged morphology, to be deposited in the neighbourhood of the PKB zones, where an extensional tectonic regime obviously operated during the whole Jurassic-Early Cretaceous interval. Therefore Plašienka (1995b) proposed a solution, which considers the Klape Unit to be derived from the Fatric Zliechov Basin, which adjoined the Meliatic collisional stack in mid-Cretaceous times and received exotic material from it (Kissová et al., 2005). During the Turonian, the Klape Unit as a part of the Krížna Nappe system slid far to the north to occupy a position in the neighbourhood of the later PKB (Plašienka and Prokešová, 1996; Prokešová et al., 2012) and was then incorporated into its structure. The Lower Senonian conglomerates, with similar composition to the Albian exotic flysch, would contain, at least partly, recycled material. If this was correct, the Klape Unit and its exotic conglomerates record important tectonic events of completely different tectonic zones of the Carpathians that have nothing in common with events occurring in wide zones along the present PKB - hence they create a kind of "false" accretionary complex (Plašienka, 1995b).

\section{ORAVIC SUCCESSIONS}

The Oravic units of the PKB were derived from the northern flanks of the South Penninic-Vahic oceanic domain, therefore their shortening and nappe stacking commenced after diminishing of the oceanic lithosphere between the Oravic continental ribbon and the active Slovakocarpathian margin. The stacking progressed from the distal passive margin (Pieniny Unit) to the Czorsztyn Ridge areas (Sub-Pieniny Unit) and finally to its northern slopes facing the North Penninic (Magura) oceanic realm. This stacking succession is well recorded by coarse-grained syn-orogenic deposits, particularly in the Eastern Slovakian PKB branch. There, three principal Oravic units have been distinguished from top to bottom - the Pieniny Nappe, the Sub-Pieniny Nappe and the Šariš Unit. While the first two are ubiquitous across the whole PKB and were recognized already by Uhlig (1907), the Šariš Unit has been defined only recently (Plašienka and Mikuš, 2010; Plašienka, 2012; Plašienka et al., 2012).

The Pieniny Nappe includes basinal successions (Pieniny sensu stricto, Kysuca-Branisko, Nižná) ranging from Lower Jurassic to Upper Cretaceous. The Pieniny-type successions are terminated by the Upper Cretaceous, coarsening- and thickening-upwards syn-orogenic sequence of Turonian distal turbidites (Snežnica Fm.) passing into Coniacian-Santonian thick-bedded sandstones with conglomerate bodies (Sromowce Fm.). The conglomerates may be regarded as "exotic" - they mostly contain material of similar composition to those described above as the Klape Flysch (Fig. 10B, C).

In the Sub-Pieniny Unit, the youngest strata of the Czorsztyn-type successions are the Upper Senonian calcareous sandstones (Jarmuta Fm.) overlain by olistostrome breccias (Gregorianka Breccia; Nemčok et al., 1989; redefined by Plašienka and Mikuš, 2010). These breccias only contain material derived from the higher Pieniny Nappe (mostly maiolicatype limestones; Fig. 10D). In the Orava region, analogous 

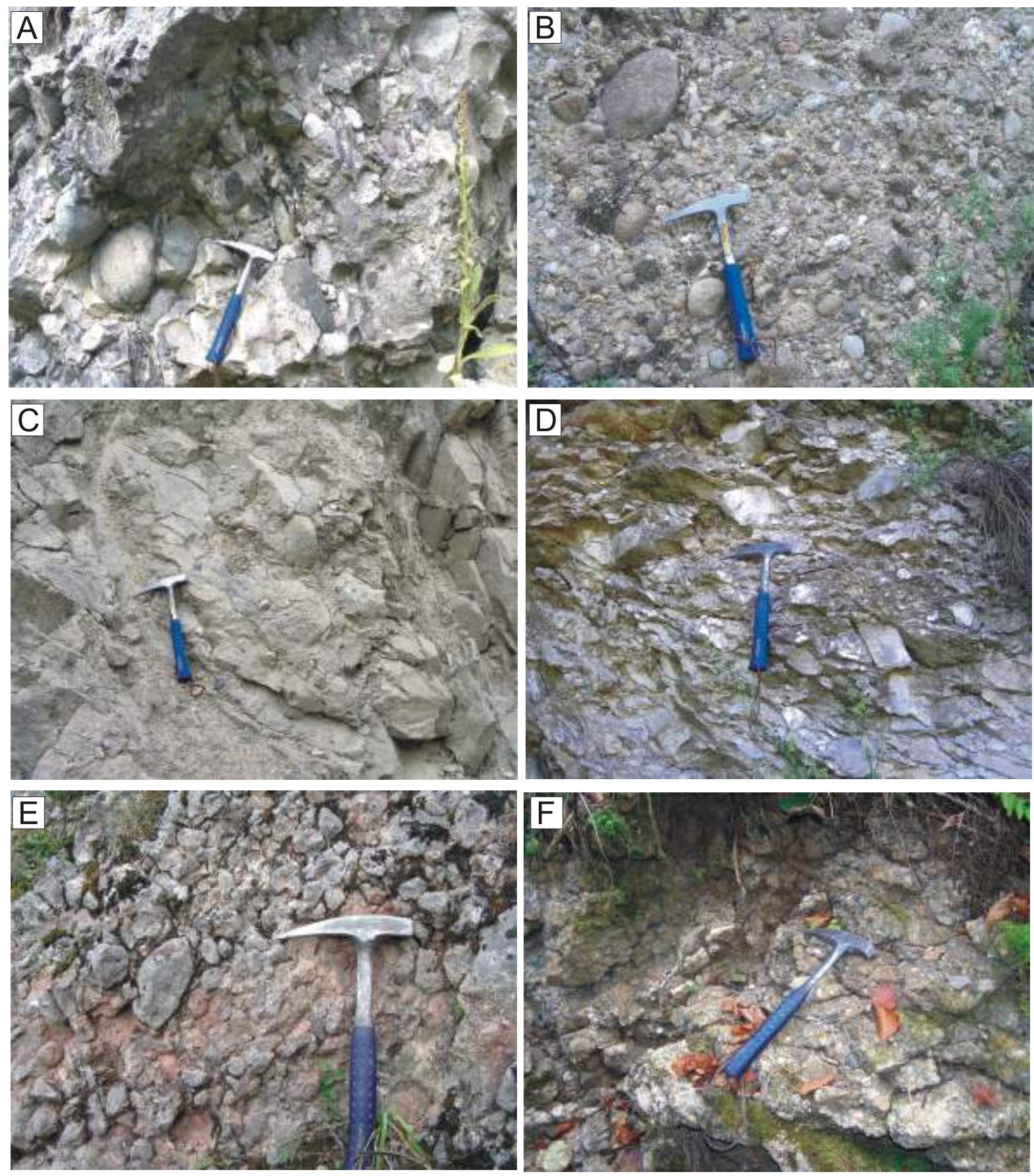

Fig. 10. Photo-table of syn-orogenic conglomerates from the PKB

A - Albian exotic conglomerates of the Klape Unit, Stupné village in the Middle Váh Valley; B - Santonian exotic conglomerates (Sromowce Fm.) of the Pieniny Unit, Oravský Podzámok village in the Orava region; $\mathbf{C}$ - pebbly mudstone (Sromowce Fm.) of the Pieniny Unit, Zemianska Dedina village in the Orava region (cf. Starek et al., 2010); D - Maastrichtian Gregorianka Breccia of the Sub-Pieniny Unit, Jarabina village in eastern Slovakia; E - Lower Eocene Milpoš Breccia of the Šariš Unit composed solely of clasts of the Middle Jurassic crinoidal limestones, Litmanová village in eastern Slovakia; F - Lower Eocene Milpoš Breccia of the Šariš Unit composed of angular clasts of various rocks derived from the PKB Oravic units mixed with well-rounded recycled exotic pebbles, Kyjov village in eastern Slovakia

Maastrichtian breccia deposits composed predominantly of material derived from the mid-Cretaceous marly units of the Kysuca-Pieniny successions, were described as olistostromes generated by disintegration of advancing nappe fronts (Záskalie Breccia; Andrusov, 1938; Marschalko et al., 1979; Baková and Soták, 2000).
The Šariš Unit was formerly considered to be a part of the "klippen mantle" (e.g., Stráník, 1965). It consists of varied Upper Jurassic to Upper Cretaceous pelagic deposits followed by Maastrichtian-Lower Eocene, deep marine, pelagic (variegated shales) and clastic (turbidite, mass-flow) deposits. The latter are known as the Jarmuta and/or Proč Fm. and involve also chaotic olistostrome bodies (Milpoš Breccia; Fig. 10E, F) 
with large olistoliths dominantly derived from the overlying Sub-Pieniny Nappe. Previously, these were mostly considered as tectonic klippen. However, their sedimentary character was recognized by Nemčok (Nemčok, 1980; Nemčok et al., 1989). The overriding Czorsztyn-type units form a system of imbricated thrust sheets. In the course of thrusting, their disintegrated fronts were transformed into precursory olistostromes inserted within and above the Proč Flysch, thus indicate close sedimentary and tectonic relationships between the Šariš and overlying units (Fig. 11; Plašienka et al., 2012).

Although the Šariš Unit, or at least some formations typical for it, can be found in many parts of the PKB, correlation of these fragments along the PKB strike meets difficulties due to locally very different interpretation of their position. In the Polish Pieniny Mts., the Šariš Unit would correspond to the Grajcarek Unit (Birkenmajer, 1970, 1986), as well as to the Hulina and Złatna units distinguished by Sikora (1971, 1974), as far as their lithological composition is concerned. However, the tectonic interpretation of both authors differs considerably from our views. Nevertheless, more recently Jurewicz (1997, 2005), Oszczypko et al. (2010), and Oszczypko and Oszczypko-Clowes (2010) proposed the lowermost structural position of the Grajcarek Unit, as an inner part of the Magura Basin, with respect to other PKB units. This view would enable correlation of the Grajcarek and Šariš units directly (see also Plašienka et al., 2012). In easternmost Slovakia, the Proč For- mation (defined originally by Leško, 1960), as the most characteristic member of the Šariš Unit, has also been affiliated to the innermost Magura Zone, hence in a lower tectonic position with respect to the PKB (Potfaj in Žec, 1997).

In the Orava region, a succession analogous to the Šariš Unit occurs in the surroundings of Zázrivá village (Soták and Plašienka, unpubl.), which was formerly in part correlated with the Cretaceous Pupov Beds (Andrusov, 1938). In the Middle Váh Valley, the Maastrichtian calcareous sandstones are commonly affiliated to the Jarmuta Formation as a terminal member of the Czorsztyn-type successions (Mello, 2011). However, our own inspection revealed that at least in the Vršatec area strata analogous to the Jarmuta-Proč Formations were partially mapped as the Javorina Beds of the Biele Karpaty Unit (Vlára Succession; Potfaj, 1993; Fig. 4). The latter unit is usually considered as a constituent of the Magura Nappe group, but considering its close structural relationship with the PKB, tectonic style (Hrouda et al., 2009), the age range (Cretaceous-Lower Eocene), general lithostratigraphic succession and prevalence of calcareous sandstones in Maastrichtian to Lower Eocene syn-orogenic deep-marine clastic deposits, it rather represents an independent tectonic element (Potfaj in Bezák, 2004) corresponding to some extent to our Šariš Unit. Moreover, Picha et al. (2006) distinguished the so-called Kopanice facies here, which according to them closely resembles the Proč-type successions of eastern Slovakia. Consequently, we infer that the

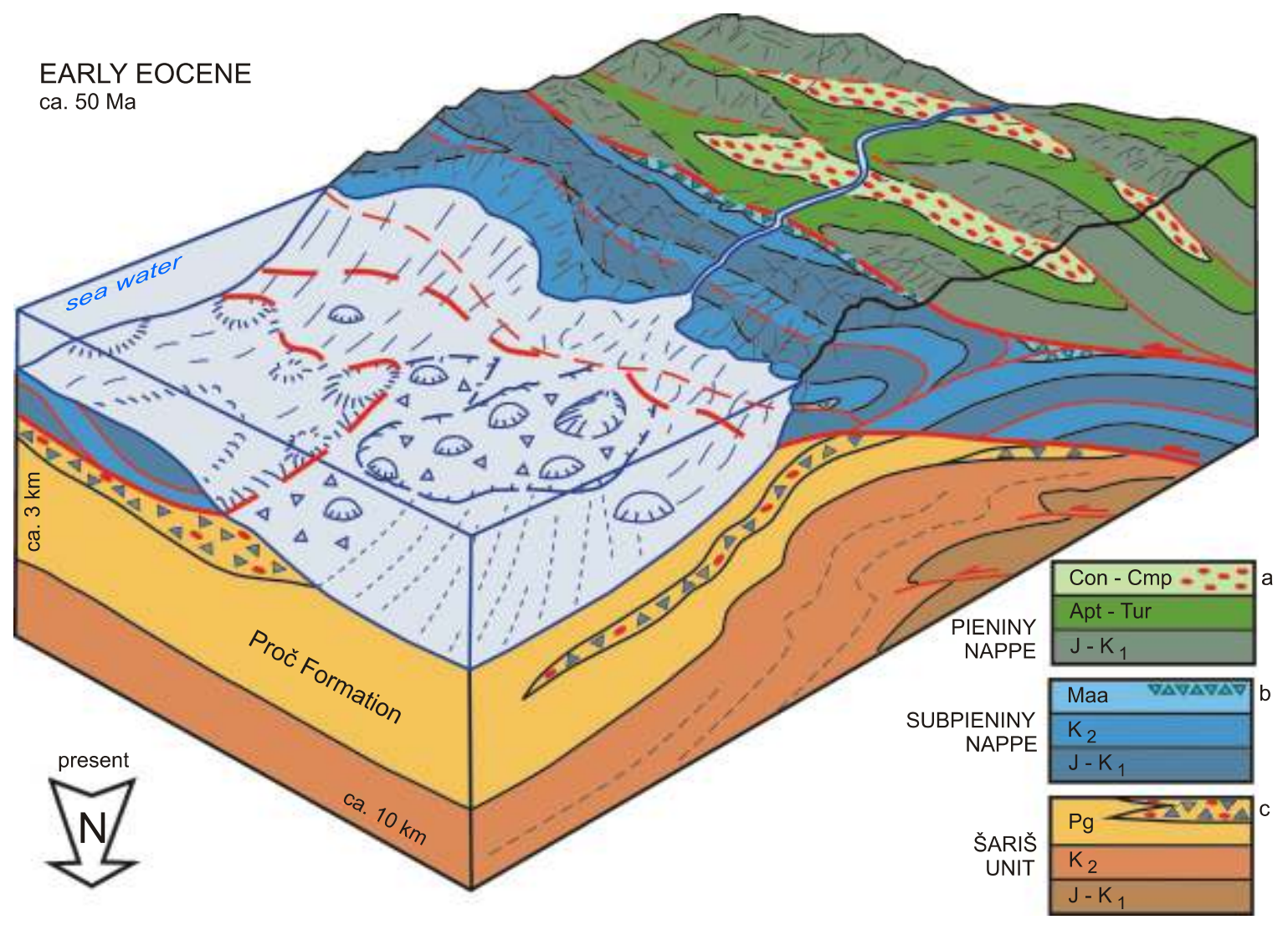

Fig. 11. Block-diagram illustrating stacking of Oravic units and position of the Proč Fm. in the eastern Slovakian Klippen Belt 
Šariš-Grajcarek-Hulina-Kopanice Unit is also a ubiquitous and integral PKB element, as are the Sub-Pieniny and Pieniny nappes.

\section{MULTIPLE RECYCLING OF THE “EXOTIC” MATERIAL}

The issue of exotic material in the Cretaceous and Paleogene conglomerates of the PKB and adjoining zones has been extensively debated for decades in the Carpathian literature. The generally accepted idea of exotic cordillera (a "cryptic ridge") on the inner side of the PKB and adjacent to the outer CWC margin was rejected by Plašienka (1995b) for the reason that the palaeotectonic and structural evolution of the outer Tatric margin is in total contradiction to what is recorded by the pebble material in these conglomerates. On the other hand, the exotic material largely mirrors those rock complexes and events which occur in the vicinity of the Meliatic units in the inner Carpathian zones. However, there was seemingly no means transporting this material through the basins and ridges of the CWC as far as the zones adjacent to the PKB. A tentative model, which assumes deposition of the Klape Flysch in the Fatric Zliechov Basin and its Upper Turonian tectonic transport in front of other Fatric Nappes (Manín-Belá, Drietoma, Krížna; Plašienka, 1995b, 1997; Kissová et al., 2005) was criticized e.g., by Mišík (1996) and Rakús and Marschalko (1997). The latter authors proposed an alternative idea of a large-scale lateral sinistral movement between the "southern" source areas and the present occurrences of exotic clasts in the western PKB branch. However, structural arguments for such movements have not yet been presented.

The exotic material first appears in large amounts in the Upper Albian-Cenomanian conglomerates of the Klape Unit and, simultaneously, in the analogous conglomerates of the Fatric and Tatric Poruba Formation (Mišík et al., 1981; see Figs. 3 and 13). It was inferred that these exotic clasts were derived from mountainous areas in the southern Austroalpine zones, which were uplifted following the Late Jurassic collision due to closure of the Meliata Ocean (Plašienka, 1995b, 1997; Kissová et al., 2005). Alternatively, part of the exotic clasts (ophiolites, highpressure metamorphic, Triassic deep-water strata) might have been derived from Jurassic mélange units related to the Neotethyan suture in these zones (e.g., Missoni and Gawlick, 2011) and mixed with material derived from exhuming basement units underlying the allochthonous mélanges in mid-Cretaceous times. Then basically the same pebble material can be found in the Coniacian-Santonian conglomerates of the Sromowce Formation of the Oravic Pieniny Unit and then, in decreasing amounts, also in the Maastrichtian Jarmuta Formation and the Paleogene Proč Formation of the PKB (Figs. 4 and 10A, B, F). Exotic pebbles have been reported also from the Senonian-Eocene conglomerates of the Gosau Group in western Slovakia. Hence the problem of the exotic pebble material does not concern only the primary source area, but also its repeated presence in units within the PKB in a time span covering ca. $60 \mathrm{Ma}$. There are several possibilities as to how to solve this problem. The classical view assumes a long-lived exotic ridge and its complete disappearance later (e.g., Andrusov, 1968; Birkenmajer, 1988), its lateral shift and an eastwards younging of exotic conglomerates along the PKB (e.g., Rakús and Marschalko, 1997; the Neopienidic cordillera of Mišík et al., 1991), or its gradual outward displacement to feed still more external and younger basins (e.g., Potfaj, 1998). The latter opinion is also supported by the present author - however, in a modified form. Instead of displacement of the original source cordillera, multiple recycling of the same exotic material to the still younger conglomerates is favoured. A tentative model of how the recycling could have occurred is outlined in Figure 12.

Exotic pebbles are unexceptionally composed of perfectly rounded hard rocks that could sustain resedimentation without substantial changes in composition and can be found unaltered also in Miocene conglomerates (Mišík, 1986) and Quaternary gravels. Concerning the Cretaceous conglomerates, Marschalko (1986) originally argued against the resedimentation of pebbles from older to younger deposits. However, Marschalko and Rakús (1997) later analysed the possibility of recycling exotic clasts within three megacycles (Albian-Cenomanian, Coniacian-Santonian and Maastrichtian-Ilerdian) and indicated that especially the olistostromes of the second cycle may have originated by disintegration of the Central Carpathian Nappe fronts, i.e. including also the pebble material. According to observations from eastern Slovakia, the still younger conglomerates (Milpoš Breccia) contain both angular carbonate material derived undoubtedly from the Oravic successions, and well-rounded siliciclastic exotic material (Nemčok et al., 1989; Plašienka et al., 2012; Fig. 10F). In this case resedimentation of the rounded material from the Sromowce conglomerates and their mixture with local, short-distance transported material appears to be the only viable explanation (Fig. 11).

\section{SHORTENING PHASES}

After closure of the Neotethyan Meliata-Hallstatt Ocean, the Western Carpathian orogenic wedge grew intermittently from the Late Jurassic onwards. The course of the wedge growth was described by Plašienka (2002; in Froitzheim et al., 2008) as follows (Fig. 13). Shortly after the Solírov Phase, in the Middle Albian, syn-orogenic, coarsening-upwards flysch sedimentation commenced in the Fatric and Tatric domains (Poruba Fm. and Klape Flysch). The mid-Cretaceous flysch sequences and their precursory carbonate olistostromes (Vlkolínec Breccia; Jablonský and Marschalko, 1992) are interpreted to reflect the development of an underthrusting zone between the Fatric and North Veporic zones during the Benkovo Phase (corresponding to the "Austrian Phase" of older authors). This stage ends with an emplacement event of extensive Fatric and Hronic cover nappe systems overriding the Tatric substratum during the Late Turonian (Donovaly Phase, pre-Gosauian or "Mediterranean"). The frontal Fatric elements (Klape, Drietoma, Manín) slid beyond the northern Tatric margin in places where they overrode the internal Vahic zones.

After diminishing of the Fatric Zliechov Basin, the compressional stresses were transmitted towards the front of the rigid Tatric plate, where an underthrusting zone of the Vahic oceanic lithosphere was set up during the Coniacian (Selec Phase, or "Subhercynian"). The subduction process continued until the Maastrichtian-Paleocene boundary, when the 
A

NW present

Albian/Cenomanian [100 Ma]

SE

sea level

Poruba-Klape Basin

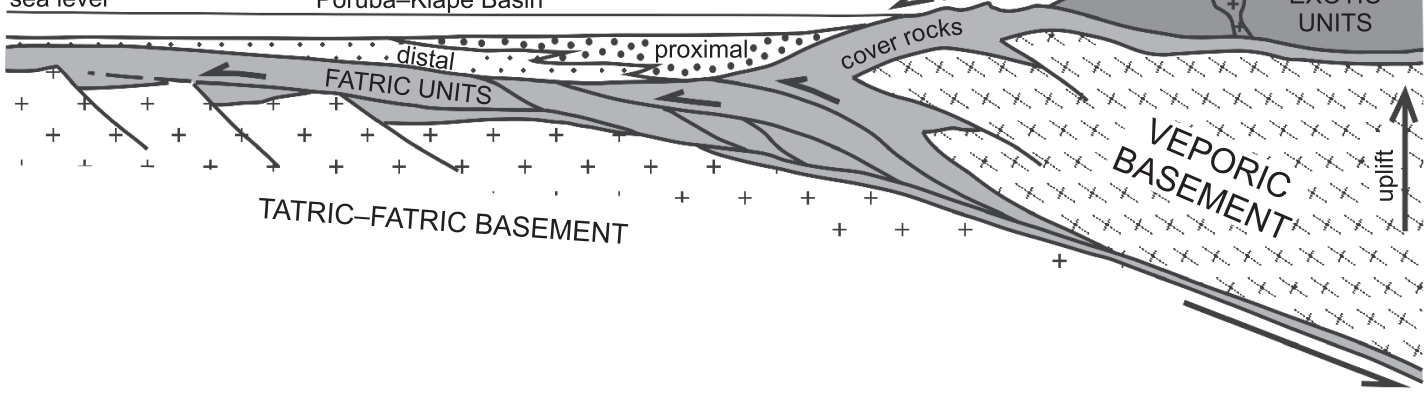

B

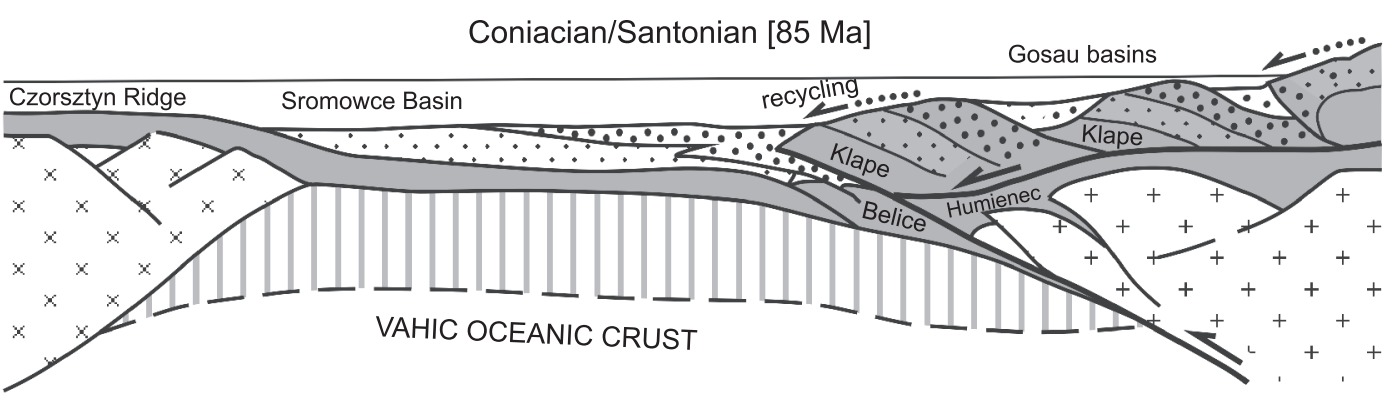

C

Campanian/Maastrichtian [70 Ma]

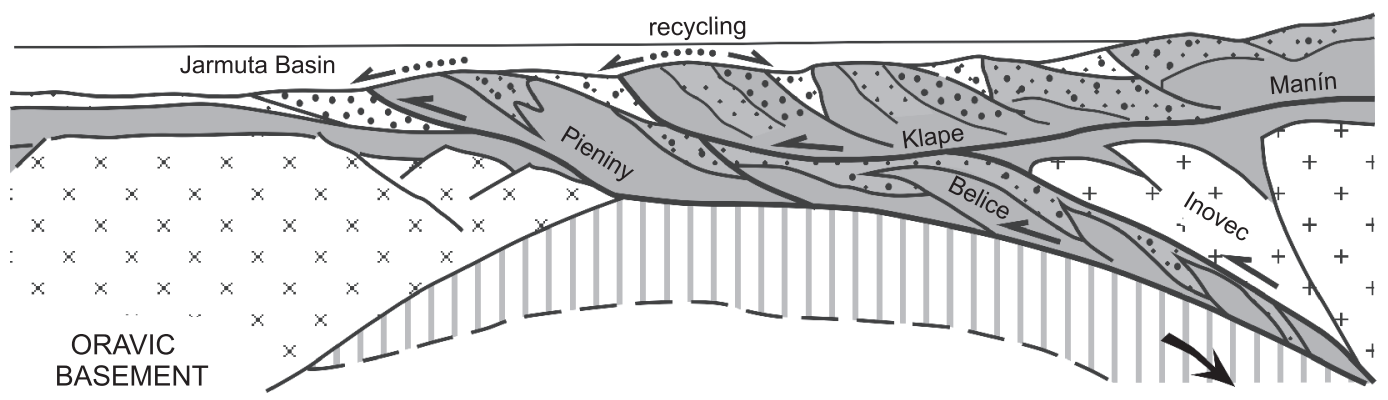

D

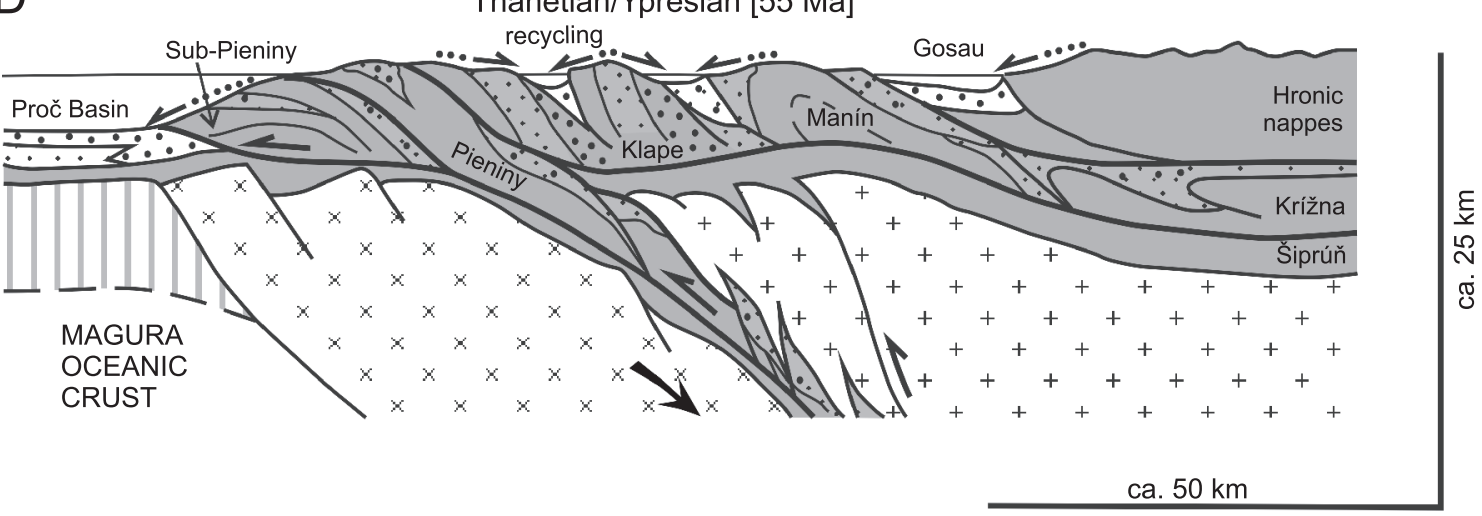

Fig. 12. Hypothetical recycling scheme of exotics in the PKB

Four principal stages of the recycling process are distinguished; $\mathbf{A}$ - primary erosion and transport of the exotic terrigenous material towards the Fatric Zliechov Basin (Poruba Fm., Klape Flysch; after Kissová et al., 2005); B - first recycling phase with resedimentation of exotic clasts from the Klape Flysch into Vahic Belice and Oravic Pieniny basins in front, and into piggy-back Gosau basins on top of the Klape "false" accretionary wedge; $\mathbf{C}$ - second recycling phase with restricted resedimentation, mostly into piggy-back Gosau basins and partly into the frontal Jarmuta Basin of the later Sub-Pieniny Unit; D - third recycling phase, increasing resedimentation from the Pieniny Unit into the frontal Proč Basin (Milpoš Breccia), but waning resedimentation into inverted Gosau basins; clastic formations are stippled, pre-existing sedimentary successions are shown grey, actively deposited clastics-dominated formations are blank 


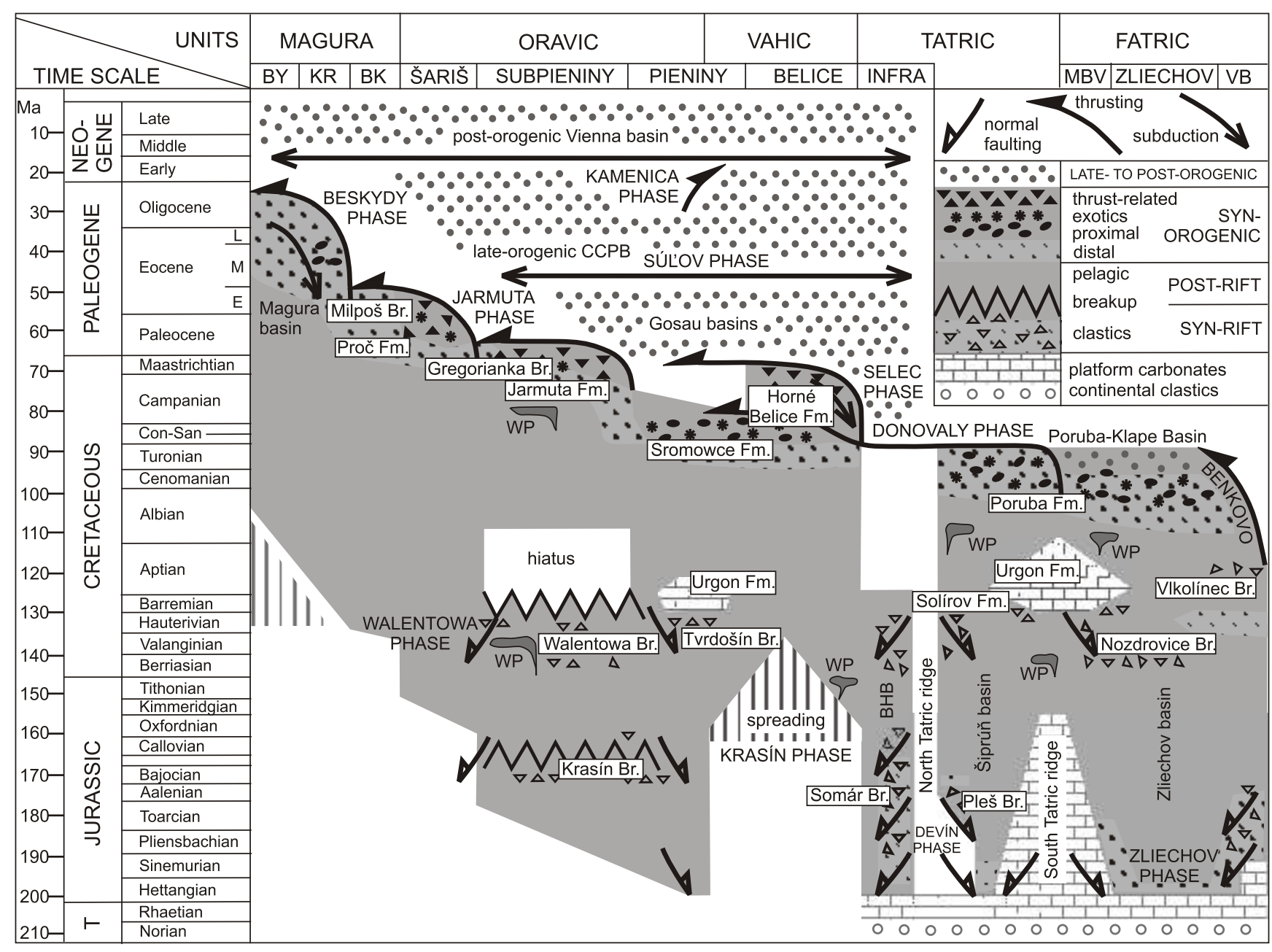

Fig. 13. Synoptic summary of syn-rift and syn-orogenic events in the outer Austroalpine and inner Penninic zones of the Western Carpathians

Note that the scheme does not represent a section, but integrates data from zones all along the Central/External Western Carpathian boundary; BHB - Borinka-Humienec Basin, BK - Biele Karpaty, BY - Bystrica, KR - Krynica, MBV - Manín-Belá-Vysoká, VB - Vel'ký Bok zones,

WP - within-plate basalts; positions of important clastic sedimentary formations and breccia members mentioned in the text are shown in boxes

collision of the wedge tip with the Oravic ribbon continent generated a strong contraction event within the wedge (Jarmuta Phase, widely known as "Laramian"). Subsequently, frontal detachment and stacking of Oravic units occurred, while their basement (Czorsztyn Ridge) were underthrust southwards beneath the wedge tip and then, during the early Paleogene, this underplated the Tatric basement thrust sheet and the overlying Cretaceous nappe stack of the CWC. Underplating of the Oravic basement caused thickening of the collisional zone, whereby the overthickened crust collapsed by the Middle Eocene and the Central Carpathian (Podhale) Paleogene Basin (CCPB) was formed (Súl'ov Phase - more-or-less "Illyrian" in former terminology). The CCPB largely sealed the PKB structures and the whole Vahic suture, but later events still partly modified the overall architecture of the suture zone. These include the Oligocene-Early Miocene forward growth of the External Carpathian accretionary wedge due to subduction of the North Penninic-Magura Ocean (Flysch Belt; e.g., Oszczypko, 1992; Winkler and Ślączka, 1994; Picha et al., 2006; Oszczypko and Oszczypko-Clowes, 2009) - this would be the Beskydy Phase ("Pyrenean" to "Savian" movements). Mani- festations of this stage as backthrusts on the inner side of the axial zone of the wedge, partly south of the PKB, are recognized as the Kamenica Phase (e.g., Plašienka et al., 1998; Marko et al., 2005; Picha et al., 2006).

The evolutionary tectonic scheme outlined in Figure 13 clearly documents the progradational trend of development of the Western Carpathian orogenic wedge during the Cretaceous. Being governed by lithospheric-scale plate tectonic processes, the shortening of the Slovakocarpathian continental basement units and subduction of the Penninic oceanic domains with intervening Oravic continental fragment indicate gradual outward migration. This polarity is expressed by younging of the principal shortening events from mid-Cretaceous times in the intra-Slovakocarpathian realms (pre-Gosauian Benkovo and subsequent Donovaly Phases), through Late Cretaceous elimination of the Vahic oceanic zone (Selec Phase) followed by the collision-related stacking of detached Oravic successions during the Early Paleogene (Jarmuta Phase), and finally by subduction of the North Penninic-Magura Ocean and development of the External Western Carpathians (Flysch Belt) accretionary wedge during the Eocene through Early Miocene 
(Beskydy Phase). However, as seen from the scheme, the Donovaly event infringes this rule in the Vahic domain, since it predates the main subduction phase of the Váh Ocean (Fig. 13). This can be explained by the structural character of the Donovaly Phase as a superficial emplacement event of the Fatric cover nappes that slid into basinal areas beyond the northern Tatric margin, i.e. they became an alien element of the subsequently developed Vahic accretionary complex. That is the reason why the Coniacian-Santonian conglomerates of the Pieniny and Belice units as a whole do not record the elimination of the Vahic oceanic zone - it was "too early", since the subduction had probably only commenced at that time. By contrast, the exotic pebble material corroborates the view assuming its resedimentation from the mid-Cretaceous Klape Flysch complexes.

\section{DISCUSSION - DISTINCTION BETWEEN SYN-RIFT AND SYN-OROGENIC COARSE CLASTICS}

Based on my observations from the Western Carpathians, I deduce some empirical conclusions concerning the differences between coarse-grained clastic deposits, predominantly marine, related to the rifting and, in contrast, to the subduction/collision processes of the South Penninic-Vahic oceanic domain and its surroundings. I rely on the overall governing tectonic regimes, not considering such other important controlling factors as sea level changes, subaerial vs. submarine derivation of the clastic material, climate and weathering conditions, or physical types of transport and deposition mechanisms. However, the differences are sometimes subtle, while the extensional vs. compressional setting is sometimes not well established (e.g., the Solírov Phase mentioned above). Consequently, no single feature can be taken as a decisive one for the distinction.

The principal distinctive attributes of the two types of mass-transfer deposits may be briefly summarized as follows (Table 1). The extension-related syn-rift breccias were exclusively fed by local, normal fault-related sources and their composition reflects ongoing denudation of the source area. Linear sources with short transport, apron-type sheet bodies interfingering basinward with hemipelagites and/or turbidites are their other common signs. Deposition might have covered a considerable time span (tens of Ma); on condition that rifting occurred in several pulses. In particular, the long-lasting rifting process was bounded to zones adjacent to the break-away fault zones of asymmetric rift structures (Borinka and Humienec successions). The wide symmetrical rifts were generally formed by a single short-time event (Zliechov and Šiprúň basins). In continuous sedimentary successions, the syn-rift clastic deposits overlie the pre-rift, often deeply eroded substratum and are overlain by deepening post-rift, mostly pelagic units. Thus their base is erosional, usually via angular unconformity and the general trend is deepening-, thinning- and fining-upwards.

In contrast, the contraction-related mass-flow deposits usually exhibit a distinct coarsening- and thickening-upwards trend, i.e. gradual transition from deep-marine strata to distal and then proximal turbidites, and finally to marginal chaotic deposits. Two basic types should be distinguished - a shorttransport type supplied by unsorted local material eroded from the overriding thrust sheet, in places supplemented to a various degree by a recycled, well-rounded pebbles (Belice and Oravic units). Under special tectonic circumstances, the recycled material can even dominate (Kysuca-Pieniny successions). Similar characteristics apply also for the piggyback growth basins of the Gosau type. Tectonosedimentary breccias carry large olistoliths and are closely related to slide bodies detached from the overriding nappe fronts. Deposition seldom exceeded a few $\mathrm{Ma}$; therefore the sedimentary age may narrowly constrain the timing of related thrusting events.

The long-transport type conglomerates were sourced by wide orogenic zones with a high-energy relief and a complex nappe structure, and were deposited in foreland-foredeep-trench basins (Poruba Fm., Klape Flysch). Owing to intermittent river and shelf environments, the clastic material is well-rounded and sorted by resistance, but still endlessly variable and often "exotic". Deposition of conglomerates and pebbly mudstones occurred in channelized proximal zones of prograding submarine turbiditic fans. Solitary slide blocks - olistoliths (Klape and Kostolec Klippen) seem to be unrelated to the conglomerates, but were emplaced during the initial stages of syn-orogenic sedimentation. In the case study presented here, though, the Klape-type conglomerates are considered as not directly linked with the closing of the Penninic-Vahic oceanic domain.

\section{CONCLUSIONS}

The zones along the External/Central Western Carpathian boundary, i.e. between the Flysch Belt and the northern Tatric margin, involve units of various and locally distant provenance and exhibit signs of extensive crustal shortening: thus, characteristics of a former plate boundary. In the interpretation presented here, the shortening resulted from diminishing of an oceanic domain correlated with the South Penninic (Ligurian-Piemont) Ocean of the Alps. It has been given the name Váh Ocean (Vahicum) in the Carpathian literature. According to the sedimentary record presented, the Vahic oceanic zone opened by passive continental rifting in several phases during the Jurassic, and closed by Late Cretaceous subduction and subsequent Maastrichtian collision of the lower plate Oravic ribbon continent (Czorsztyn Ridge) with the upper plate of the Tatric (Austroalpine-Slovakocarpathian) margin (Fig. 13). Both the rifting and collision processes are recorded in clastic strata, among them noticeably coarse-grained deposits that comprise the main object of this overview study. I have presented the most significant examples of both the rifting-related and syn-orogenic conglomerates/breccias of various units that are interpreted as vestiges of opening and closure of the Váh Ocean.

The extensional regime is exemplified by the normal fault-related scarp breccias of the Jurassic Borinka Unit in the Malé Karpaty Mts. These were deposited in a halfgraben flanking the Tatric continental margin against the Vahic Ocean. Breccias form up to $100 \mathrm{~m}$ thick, sheet-like bodies composing basinwards thinning aprons with exposed cumulative thickness exceeding $500 \mathrm{~m}$. Near the halfgraben axis the breccia bodies interfinger with basinal hemipelagic or sandy turbidite-dominated deposits. The clastic material is unsorted and always angular, olistoliths reaching $100 \mathrm{~m}$ in diameter. The clast compo- 
Comparison of main characteristics of the mass-flow deposits in extensional and compressional settings

\begin{tabular}{|c|c|c|c|}
\hline \multirow{2}{*}{ Tectonic regime } & \multirow{2}{*}{ Extension } & \multicolumn{2}{|c|}{ Compression } \\
\hline & & Short transport & Long transport \\
\hline Setting & $\begin{array}{l}\text { extensional; continental rift zones } \\
\text { to passive margins }\end{array}$ & $\begin{array}{l}\text { thrusting/contractional; thrust sheet } \\
\text { or gliding nappe fronts }\end{array}$ & $\begin{array}{c}\text { forelands of actively deforming } \\
\text { orogenic zones }\end{array}$ \\
\hline $\begin{array}{l}\text { Position } \\
\text { Basin type }\end{array}$ & $\begin{array}{l}\text { foots of normal fault scarps } \\
\text { marine, often halfgrabens }\end{array}$ & $\begin{array}{c}\text { fronts of advancing nappes } \\
\text { deep-marine foredeep/trench }\end{array}$ & $\begin{array}{l}\text { proximal parts of turbidite fans } \\
\text { deep-marine foreland and foredeep }\end{array}$ \\
\hline Source/deposit separation & normal to strike-slip fault & thrust fault & foredeep- or trench-arc gap \\
\hline Pnumprovenance & local footwall sources & local hangingwall sources & distant, often unidentified sources \\
\hline Material & $\begin{array}{l}\text { angular, unsorted, clast-supported } \\
\text { (mixtites) }\end{array}$ & $\begin{array}{c}\text { mostly angular, poorly sorted, } \\
\text { mostly clast-supported }\end{array}$ & $\begin{array}{l}\text { rounded, well-sorted, frequently } \\
\text { matrix-supported }\end{array}$ \\
\hline $\begin{array}{l}\text { Sources } \\
\text { Derivation }\end{array}$ & $\begin{array}{c}\text { linear sources } \\
\text { footwall erosion and denudation }\end{array}$ & $\begin{array}{c}\text { linear to point sources fragmentation } \\
\text { and erosion of the overriding } \\
\text { thrust sheet }\end{array}$ & $\begin{array}{l}\text { sourced from large areas } \\
\text { erosion of mountainous relief }\end{array}$ \\
\hline Recycling & absent & frequent, even multiple & absent or rare \\
\hline Sedimentary forms & sheet-like bodies - aprons & $\begin{array}{l}\text { irregular bodies - slumps, channel } \\
\text { fillings, aprons }\end{array}$ & $\begin{array}{c}\text { channel fills, boulder beds, } \\
\text { pebbly mudstones }\end{array}$ \\
\hline Associations & $\begin{array}{l}\text { proximal zones: shallow-marine } \\
\text { bio- or siliciclastic sediments; } \\
\text { distal zones: hemipelagites and/or } \\
\text { turbidites }\end{array}$ & $\begin{array}{l}\text { deep-marine hemipelagites, fine- } \\
\text { to coarse-grained sandy turbidites } \\
\text { and fluxoturbidites }\end{array}$ & $\begin{array}{l}\text { deep-marine (hemi)pelagites, } \\
\text { fine- to coarse-grained sandy } \\
\text { turbidites }\end{array}$ \\
\hline Boundaries & $\begin{array}{l}\text { base angular unconformity } \\
\text { top gradual fining-upward }\end{array}$ & $\begin{array}{l}\text { base coarsening-upward } \\
\text { top tectonic thrust fault }\end{array}$ & $\begin{array}{l}\text { base coarsening-upward } \\
\text { top tectonic or erosional }\end{array}$ \\
\hline Demise & post-rift subsidence or inversion & burial under overriding sheet & inversion, involvement in thrusting \\
\hline Duration & $\begin{array}{l}\text { tens of Ma (if several rift } \\
\text { phases occurred) }\end{array}$ & $\begin{array}{l}\text { a few Ma, maybe even less (single } \\
\text { thrust event, gliding nappes) }\end{array}$ & orogenic phase (10-15 Ma) \\
\hline Terminology & $\begin{array}{l}\text { syn-rift - tectonosedimentary breccia, } \\
\text { scarp breccia }\end{array}$ & $\begin{array}{l}\text { syn-orogenic - wildflysch, precur- } \\
\text { sory olistostromes }\end{array}$ & $\begin{array}{l}\text { syn-orogenic or shortly pre-orogenic } \\
\text { - conglomeratic flysch }\end{array}$ \\
\hline
\end{tabular}

sition reveals gradual erosion of local source areas from pre-rift Triassic carbonates and quartzites (Lower Jurassic breccias) to basement rocks (Middle to Upper Jurassic breccias). The linear sources - fault escarpments were active for at least $30 \mathrm{Ma}$, during which two or three major rift pulses may be documented. The Jurassic-Early Cretaceous rifting processes are further demonstrated by areally restricted cases of scarp breccias entirely destroyed by later compressional events at the Infratatric margin (reconstructed Humienec Succession), and by the breccias occurring on the other side of the ocean in the Oravic Sub-Pieniny Unit of the PKB (Czorsztyn Succession). The latter are interpreted as connected with the breakup of its bounding South Penninic-Vahic (Bajocian Krasín Breccia) and North Penninic-Magura oceans (Lower Cretaceous Walentowa and Tvrdošín breccias).

Syn-orogenic sedimentary units related to compressional tectonic regimes terminate the sedimentary successions of inverted basins. In the course of ongoing deformation, they were often destroyed shortly after origin and their material could be recycled several times. Syn-orogenic breccias/conglomerates contain a variety of material derived either from wide orogenic zones characterized by a complex geological structure (long transport), or from local sources of advancing thrust fronts approaching the foredeep depressions (short transport). The contraction-related conglomerates and mass-flow deposits usually exhibit a coarsening- and thickening-upwards trend. Deposition of the short-transport sediments seldom exceeded a few Ma, maybe less, thus their stratigraphic age can narrowly constrain timing of related thrusting events.
Two areas provide examples of contractional settings, both related to shortening and closure of the Penninic-Vahic oceanic domain. The Belice Unit in the Považský Inovec Mts. includes Upper Jurassic-Lower Cretaceous eupelagic, mostly siliceous strata and a thickening-upwards Senonian sequence of turbiditic sandstones, conglomerates and chaotic breccias composed of material derived from the overriding Infratatric Inovec basement/cover nappe. It is inferred that this succession represents the sedimentary cover of an oceanic crust approaching the trench position, its offscraping and incorporation into the accretionary complex, and finally underthrusting below the outer Tatric (Infratatric) margin.

The marine breccia/conglomerate bodies with olistoliths in the PKB formed in response to the collision-related thrust stacking of the Oravic units and their composition directly reflects the lithology of the overriding thrust sheets. Thrusting started during the Maastrichtian and is recorded by the Gregorianka Breccia in the Sub-Pieniny Unit, which contain material derived from the overriding Pieniny Nappe. After that, the Sub-Pieniny Unit was detached from its basement substratum and was thrust over the frontal Jarmuta-Proč Basin of the later Šariš Unit. Thrusting began during the Paleocene and was terminated by the Lower Eocene, being recorded by the Milpoš Breccia composed of very variegated material - predominantly carbonates derived from the Sub-Pieniny Unit, but also from the Pieniny Unit. Numerous "klippen" of the PKB rest within these breccias and hence they are in fact olistoliths - a feature often overlooked until now. The locally frequent exotic siliciclastic material in breccias is well-rounded and it is in- 
ferred that it is recycled from the Coniacian-Santonian conglomerates of the Pieniny Unit.

The long-transport syn-orogenic exotic conglomerates, which are so frequent in the PKB, most probably do not reflect events that occurred in their present places of occurrence. They are interpreted to have been deposited during the Albian-Cenomanian, originally in the Fatric Zliechov Basin in the proximity of the Veporic-Gemeric-Meliatic-Silicic collisional orogenic belt in the southern Carpathian zones. During the Late Turonian the conglomerates, as constituents of the Klape Flysch, slid in front of other Fatric nappes beyond the northern Tatric margin. There they have overlain the southern Vahic zones to create a "false" accretionary wedge, from which the exotic material was recycled to younger Senonian to Paleogene conglomerates of various PKB units.
Acknowledgements. This paper is dedicated to two excellent personalities in Carpathian geological research, professors N. Oszczypko and A. Ślączka. Their contribution to our understanding of the sedimentology of the clastic units and the palaeogeographic and tectonic evolution of the Outer Carpathians is outstanding and laid the foundations for any further investigations in these fields. The author is indebted to the reviewers Prof. H.-J. Gawlick, Dr. M. Krobicki, Dr. J. Soták and to one anonymous one, as well as to the scientific editor Prof. T.M. Peryt for valuable comments and suggestions that helped to improve the scientific level of this paper. Many thanks go also to Mrs. V. Némethová for the technical assistance in drawing the figures. Financial support from the Slovak Research and Development Agency (projects SK-AT-0014-10 and ESF-EC-0006-07) and the VEGA Scientific Grant Agency (projects 1/0388/10 and $1 / 0712 / 11$ ) is gratefully acknowledged.

\section{REFERENCES}

ABBATE E., BORTOLOTTI V. and PASSERINI P. (1970) - Olistostromes and olistoliths. Sedim. Geol., 4 (3-4): 521-557.

ANDRUSOV D. (1938) - Étude géologique de la zone des Klippes internes des Carpathes Occidentales. IIIe partie: Tectonique. Rozpr. St. Geol. Ústavu ČSR, 9: 1-135.

ANDRUSOV D. (1968) - Grundriss der Tektonik der Nördlichen Karpaten. Vyd. Slov. Akad. Vied, Bratislava.

AUBRECHT R. (1994) - Hauterivian turbidites in the Kysuca Unit (Pieniny Klippen Belt, West Carpathians). Miner. Slov., 26: 250-254.

AUBRECHT R. and OŽVOLDOVÁ L. (1994) - Middle Jurassic-Lower Cretaceous development of the Pruské Unit in the western part of the Pieniny Klippen Belt. Geol. Carpath., 45: 211-223.

AUBRECHT R. and SÝKORA M. (1998) - Middle Jurassic crinoidal shoal complex at Hatné-Hrádok locality (Czorsztyn Unit, Pieniny Klippen Belt, western Slovakia). Miner. Slov., 30: 157-166.

AUBRECHT R. and SZULC J. (2006) - Deciphering of the complex depositional and diagenetic history of a scarp limestone breccia (Middle Jurassic Krasin Breccia, Pieniny Klippen Belt, Western Carpathians). Sedim. Geol., 186: 265-281.

AUBRECHT R., MIŠÍK M. and SÝKORA M. (1997) - Jurassic synrift sedimentation on the Czorsztyn Swell of the Pieniny Klippen Belt in western Slovakia. In: Alpine evolution of the Western Carpathians and related areas (eds. D. Plašienka, J. Hók, J. Vozár and M. Elečko): 53-64. Geol. Surv. Slov. Rep., D. Štúr Publ., Bratislava.

AUBRECHT R., KROBICKI M., SÝKORA M., MIŠÍK M., BOOROVÁ D., SCHLÖGL J., ŠAMAJOVÁ E. and GOLONKA J. (2006) - Early Cretaceous hiatus in the Czorsztyn Succession (Pieniny Klippen Belt, Western Carpathians): submarine erosion or emersion? Ann. Soc. Geol. Pol., 76: 161-196.

BAKOVÁ L. and SOTÁK J. (2000) - Tectonosedimentary formations of the Pieniny Klippen Belt (Orava, Slovakia): structural styles of melanges and olistostromes. Slovak Geol. Mag., 6 (2-3): 198-199.

BEHR H.J., ENGEL W. and FRANKE W. (1982) - Variscan wildflysch and nappe tectonics in the Saxothuringian zone (Northeast Bavaria, West Germany). Am. J. Sc., 282: 1438-1470.

BERNOULLI D., BERTOTTI G. and FROITZHEIM N. (1993) - Mesozoic faults and associated sediments in the Austroalpine-South Alpine passive continental margin. Mem. Soc. Geol. It., 45: 25-38.

BEZÁK V., ed. (2004) - Tectonic map of Slovak Republic 1:500,000 and Explanations. MŽP SR, ŠGÚDŠ, Bratislava.

BIELIK M., ŠEFARA J., KOVÁČ M., BEZÁK V. and PLAŠIENKA D. (2004) - The Western Carpathians - interaction of Hercynian and Alpine processes. Tectonophysics, 393: 63-86.
BIRKENMAJER K. (1970) - Pre-Eocene fold structures in the Pieniny Klippen Belt (Carpathians) of Poland (in Polish with English summary). Studia Geol. Pol., 31: 5-81.

BIRKENMAJER K. (1977) - Jurassic and Cretaceous lithostratigraphic units of the Pieniny Klippen Belt, Carpathians, Poland (in Polish with English summary). Studia Geol. Pol., 45: 3-159.

BIRKENMAJER K. (1986) - Stages of structural evolution of the Pieniny Klippen Belt, Carpathians. Studia Geol. Pol., 88: 7-32.

BIRKENMAJER K. (1988) - Exotic Andrusov Ridge: its role in plate-tectonic evolution of the West Carpathian foldbelt. Studia Geol. Pol., 41: 7-37.

BIRKENMAJER K., KOZUR H. and MOCK R. (1990) - Exotic Triassic pelagic limestone pebbles from the Pieniny Klippen Belt of Poland: a further evidence for Early Mesozoic rifting in West Carpathians. Ann. Soc. Geol. Pol., 60 (1-4): 3-44.

BUCK W.R. (1991) - Modes of continental lithospheric extension. J. Geophys. Res., 96: 20161-20178.

CAMERLENGHI A. and PINI G.A. (2009) - Mud volcanoes, olistostromes and Argille scagliose in the Mediterranean region. Sedimentology, 56: 319-365.

CIESZKOWSKI M., GOLONKA J., KROBICKI M., ŚLĄCZKA A., OSZCZYPKO N., WAŚKOWSKA A. and WENDORFF M. (2009) The Northern Carpathians plate tectonics evolutionary stages and origin of olistoliths and olistostromes. Geodin. Acta, 22 (1-3): 101-126.

CLAUDEL M.-E. and DUMONT T. (1999) - A record of multistage continental break-up on the Briançonnais marginal plateau (Western Alps): Early and Middle-Late Jurassic rifting. Ecl. Geol. Helv., 92: 45-61.

DAL PIAZ G.V., MARTIN S., VILLA I.M., GOSSO G. and MARSCHALKO R. (1995) - Late Jurassic blueschist facies pebbles from the Western Carpathian orogenic wedge and paleostructural implications for Western Tethys evolution. Tectonics, 14: 874-885.

DECKER K. (1990) - Plate tectonics and pelagic facies: Late Jurassic to Early Cretaceous deep-sea sediments of the Ybbsitz ophiolite unit (Eastern Alps, Austria). Sedim. Geol., 67: 85-99.

DECKER K., FAUPL P. and MÜLLER A. (1987) - Synorogenic sedimentation on the Northern Calcareous Alps during the Early Cretaceous. In: Geodynamics of the Eastern Alps (eds. H.W. Flügel and P. Faupl) 126-141. Franz Deuticke, Vienna.

DIETRICH V. (1970) - Die Stratigraphie der Platta-Decke. Fazielle Zusammenhänge zwischen Oberpenninikum und Unterostalpin. Ecl. Geol. Helv., 63: 631-671.

DIMITRIJEVIĆ M.N., DIMITRIJEVIĆ M.D., KARAMATA S., SUDAR M., GERZINA N., KOVÁCS S., DOSZTÁLY L., GULÁCSI Z., 
LESS G. and PELIKÁN P. (2003) - Olistostrome/mélanges - an overview of the problems and preliminary comparison of such formations in Yugoslavia and NE Hungary. Slovak Geol. Mag., 9: 3-21.

DUMONT T. (1988) - Late Triassic-early Jurassic evolution of the western Alps and their European foreland; initiation of the Tethyan rifting. Bull. Soc. Géol. France, 4 (4): 601-611.

DUNKL I. and DEMÉNY A. (1997) - Exhumation of the Rechnitz Window at the border of the Eastern Alps and Pannonian Basin during Neogene extension. Tectonophysics, 272 (2-4): 197-211.

EBERLI G.P. (1988) - The evolution of the southern continental margin of the Jurassic Tethys Ocean as recorded in the Allgäu Formation of the Austroalpine nappes of Graubünden (Switzerland). Ecl. Geol. Helv., 81: $175-214$

EBNER F., VOZÁROVÁ A., KOVÁCS S., KRÄUTNER H.-G., KRSTIĆ B., SZEDERKÉNYI T., JAMIČIĆ D., BALEN D., BELAK M. and TRAJANOVA M. (2008) - Devonian-Carboniferous pre-flysch and flysch environments in the Circum Pannonian Region. Geol. Carpath., 59 (2): 159-195.

ELTER P. and TREVISAN L. (1973) - Olistostromes in the tectonic evolution of the northern Apennines. In: Gravity and Tectonics (eds. K.A de Jong and R. Scholten): 175-188. John Wiley and Sons, New York.

FARYAD S.W. and SCHREYER W. (1996) - Petrology and geological significance of high-pressure metamorphic rocks occurring as pebbles in the Cretaceous conglomerates of the Klippen Belt (West Carpathians, Slovakia). Eur. J. Miner., 9: 547-562.

FAUPL P. and WAGREICH M. (1992) - Cretaceous flysch and pelagic sequences of the Eastern Alps: correlations, heavy minerals, and palaeogeographic implications. Cret. Res., 13: 387-403.

FAUPL P., POBER E. and WAGREICH M. (1987) - Facies development of the Gosau Group of the eastern parts of the Northern Calcareous Alps during the Cretaceous and Paleogene. In: Geodynamics of the Eastern Alps (eds. H.W. Flügel and P. Faupl): 142-155. Franz Deuticke, Vienna.

FEDOROV E.G. (1987) - Olistostromy i olistolity v karbone Juzhnogo Tian-Shania (in Russian). Soviet. Geol., 1987 (2): 89-96.

FESTA A., PINI G.A., DILEK Y., CODEGONE G., VEZZANI L., GHISETTI F., LUCENTE C.C. and Ogata K. (2010a) - Peri-Adriatic mélanges and their evolution in the Tethyan realm. Int. Geol. Rev., 52 (4-6): 369-403.

FESTA A., PINI G.A., DILEK Y. and CODEGONE G. (2010b) - Mélanges and mélange-forming processes: a historical overview and new concepts. Int. Geol. Rev., 52 (10-12): 1040-1105.

FINGER W. (1978) - Die Zone von Samaden (Unterostalpine Decken, Graubünden) und ihre Jurassischen Brekzien. Abh. ETH Zürich, N.F., 224.

FLORINETH D. and FROITZHEIM N. (1994) - Transition from continental to oceanic basement in the Tasna nappe (Engadine window, Graubünden, Switzerland): evidence for Early Cretaceous opening of the Valais ocean. Schweiz. Miner. Petrogr. Mitt., 74: 437-448.

FRANKE W. and ENGEL W. (1986) - Synorogenic sedimentation in the Variscan Belt of Europe. Bull. Soc. Géol. France, 1: 25-33.

FRISCH W. (1979) - Tectonic progradation and plate tectonic evolution of the Alps. Tectonophysics, 60: 121-139.

FRISCH W. (1981) - Plate motions in the Alpine region and their correlation to the opening of the Atlantic ocean. Geol. Rd., 70: 402-411.

FRISCH W. and GAWLICK H.-J. (2003) - The nappe structure of the Northern Calcareous Alps and its disintegration during Miocene tectonic extrusion - a contribution to understanding the orogenic evolution of the Eastern Alps. Int. J. Earth Sc. (Geol. Rd.), 92: 712-727.

FRISCH W., GOMMERINGER K., KELM U. and POPP F. (1987) - The upper Bündner Schiefer of the Tauern Window - a key to understanding Eoalpine orogenic processes in the Eastern Alps. In: Geodynamics of the Eastern Alps (eds. H.W. Flügel and P. Faupl): 55-69. Franz Deuticke, Wien.

FROITZHEIM N. (1988) - Synsedimentary and synorogenic normal faults within a thrust sheet of the Eastern Alps (Ortler zone, Graubünden, Switzerland). Ecl. Geol. Helv., 81 (3): 593-610.

FROITZHEIM N. and EBERLI G.P. (1990) - Extensional detachment faulting in the evolution of a Tethys passive continental margin, Eastern Alps, Switzerland. GSA Bull., 102: 1297-1308.

FROITZHEIM N. and MANATSCHAL G. (1996) - Kinematics of Jurassic rifting, mantle exhumation, and passive-margin formation in the
Austroalpine and Penninic nappes (eastern Switzerland). GSA Bull., 108: $1120-1133$.

FROITZHEIM N., PLAŠIENKA D. and SCHUSTER R. (2008) - Alpine tectonics of the Alps and Western Carpathians. In: The Geology of Central Europe. Volume 2: Mesozoic and Cenozoic (ed. T. McCann): 1141-1232. Geol. Soc. Publ. House, London.

FÜCHTBAUER H. and RICHTER D.K. (1983) - Relations between submarine fissures, internal breccias and mass flows during Triassic and earlier rifting periods. Geol. Rd., 72 (1): 53-66.

GAWLICK H.-J., FRISCH W., VECSEI A., STEIGER T. and BÖHM F (1999) - The change from rifting to thrusting in the Northern Calcareous Alps as recorded in Jurassic sediments. Geol. Rd., 87: 644-657.

HAAS J., KOVÁCS S., KARAMATA S., SUDAR M., GAWLICK H.-G., GRĂDINARU E., MELLO J., POLÁK M., PÉRÓ CS., OGORELEC B. and BUSER S. (2010) - Jurassic environments in the Circum-Pannonian Region. In: Variscan and Alpine Terranes of the Circum-Pannonian Region (eds. J. Vozár, F. Ebner, A. Vozárová, J. Haas, S. Kovács, M. Sudar, M. Bielik and C. Péró): 159-195. Geol. Inst., Slov. Acad. Sc.

HANDY M.R. (1996) - The transition from passive to active margin tectonics: a case study from the zone of Samedan (eastern Switzerland). Geol. Rd., 85 (4): 832-851.

HÄUSLER H. (1988) - Unterostalpine Jurabreccien in Österreich Versuch einer sedimentologischen und paläogeographischen Analyse nachtriadischer Breccienserien im unterostalpinen Rahmen des Tauernfensters (Salzburg - Tirol). Jb. Geol. B-A., 131: 21-125.

HÄUSLER H., PLAŠIENKA D. and POLÁK M. (1993) - Comparison of Mesozoic successions of the Central Eastern Alps and the Central Western Carpathians. Jb. Geol. B.-A., 136: 715-739.

HEUBECK C. (1992) - Sedimentology of large olistoliths, southern Cordillera Central, Hispaniola. J. Sed. Petrol., 62 (3): 474-482.

HOMAYOUN M. and FAUPL P. (1992) - Unter- und Mittelkreideflysch der Ybbsitzer Klippenzone (Niederösterreich). Mitt. Ges. Geol. Bergbaustud. Österr., 38: 1-20.

HROUDA F., KREJČÍ O., POTFAJ M. and STRÁNÍK Z. (2009) - Magnetic fabric and weak deformation in sandstones of accretionary prisms of the Flysch and Klippen Belts of the Western Carpathians: Mostly offscraping indicated. Tectonophysics, 479: 254-270.

HSÜ K.J. (1974) - Mélanges and their distinction from olistostromes. SEPM Spec. Publ., 19: 321-333.

IVANIČKA J. and KOHÚT M., eds. (2011) - Explanations to the geological map of the Považský Inovec Mts. and south-eastern part of Trenčianska kotlina basin 1:50 000 (in Slovak with English summary). State Geol. Inst. D. Štúr, Bratislava

JABLONSKÝ J. (1978) - Contribution to knowledge of the Albian of the Zliechov Group in the Strážovské vrchy Mts. (in Slovak with English summary). In: Paleogeographic Evolution of the Western Carpathians (ed. J. Vozár): 175-187. Konf. Symp. Sem., GÚDŠ, Bratislava.

JABLONSKÝ J. and MARSCHALKO R. (1992) - Pre-flysch olistostromes in Central Western Carpathians, Barremian-Aptian of Krížna Nappe, Slovakia. Geol. Carpath., 43: 15-20.

JABLONSKÝ J., MICHALÍK J., PLAŠIENKA D. and SOTÁK J. (1993) Sedimentary environments of the Solírov Formation and correlation with Lower Cretaceous turbidites in Central West Carpathians, Slovakia. Cret. Res., 14: 613-621.

JABLONSKÝ J., SÝKORA M. and AUBRECHT R. (2001) - Detritic Cr-spinels in Mesozoic sedimentary rocks of the Western Carpathians (overview of the latest knowledge) (in Slovak with English summary). Miner. Slov., 33: 487-498.

JÓZSA Š. and AUBRECHT R. (2008) - Barremian-Aptian erosion of the Kysuca-Pieniny trough margin (Pieniny Klippen Belt, Western Carpathians). Geol. Carpath., 59 (2): 103-116.

JUREWICZ E. (1997) - The contact between the Pieniny Klippen Belt and Magura Unit (the Małe Pieniny Mts.). Geol. Quart., 41 (3): 315-326.

JUREWICZ E. (2005) - Geodynamic evolution of the Tatra Mts. and the Pieniny Klippen Belt (Western Carpathians): problems and comments. Acta Geol. Pol., 55: 295-338.

KISSOVÁ D., DUNKL I., PLAŠIENKA D., FRISCH W. and MARSCHALKO R. (2005) - The Pieninic exotic cordillera (Andrusov Ridge) revisited: new zircon FT ages of granite pebbles from Cretaceous conglomerates of the Pieniny Klippen Belt (Western Carpathians, Slovakia). Slovak Geol. Mag., 11: 17-28. 
KOPTEVA V.V. (1981) - Osadochno-tektonicheskiye brektsii "Gadilevskoy tolshchi" (Juzhnyj Ural) (in Russian). Litol. Polezn. Iskop., 1981 (1): 55-68.

KOVÁCS S. (1988) - Olistostromes and other deposits connected to subaqueous mass-gravity transport in the North Hungarian Paleo-Mesozoic. Acta Geol. Hung., 31 (3-4): 265-287.

KOVÁCS S., HAAS J., OZSVÁRT P., PALINKAŠ L.A., KISS G., MOLNÁR F., JÓZSA S. and KÖVÉR Sz. (2010) - Re-evaluation of the Mesozoic complexes of Darnó Hill (NE Hungary) and comparisons with Neotethyan accretionary complexes of the Dinarides and Hellenides - preliminary data. Central Eur. Geol., 53 (2-3): 205-231.

KÖVÉR SZ., HAAS J., OZSVÁRT P., GÖRÖG Á., GÖTZ A.E. and JÓZSA S. (2009) - Lithofacies and age data of Jurassic foreslope and basin sediments of Rudabánya Hills (NE Hungary) and their tectonic interpretation. Geol. Carpath., 60 (5): 351-379.

KOZUR H. (1991) - The evolution of the Meliata-Hallstatt ocean and its significance for the early evolution of the Eastern Alps and Western Carpathians. Palaeogeogr. Palaeoclimatol. Palaeoecol., 87: 109-135.

KROBICKI M. (2009) - Bajocian synsedimentary tectonics and its significance in Jurassic evolution of the Pieniny Klippen Basin (in Polish with English summary). Geologia, 35 (3/1): 65-78.

KROBICKI M. and WIERZBOWSKI A. (2004) - Stratigraphic position of the Bajocian crinoidal limestones and their palaeogeographic significance in evolution of the Pieniny Klippen Basin (in Polish with English abstract). Tomy Jurajskie, 2: 69-82.

KROBICKI M., GOLONKA J. and SŁOMKA T. (2010) - Latest Jurassic-earliest Cretaceous mass movements in the Polish part of the Pieniny Klippen Belt and Silesian Unit (Outer Flysch Carpathians). Sc. Ann., School Geol., Aristotle Univ. Thessaloniki. Proc. XIX CBGA Congress, Thessaloniki, Greece. Spec. Vol., 100: 209-219.

KURZ W., NEUBAUER F., GENSER J. and DACHS E. (1998) - Alpine geodynamic evolution of passive and active continental margin sequences in the Tauern Window (eastern Alps, Austria, Italy): a review. Geol. Rd., 87: 225-242.

LEFELD J., GA DZICKI A., IWANOW A., KRAJEWSKI K. and WÓJCIK K. (1985) - Jurassic and Cretaceous lithostratigraphic units of the Tatra Mountains. Studia Geol. Pol., 84: 5-93.

LEMOINE M. and TRÜMPY R. (1987) - Pre-oceanic rifting in the Alps. Tectonophysics, 133: 305-320.

LEMOINE M., BAS T., ARNAUD-VANNEAN A., ARNAUD H., DUMONT T., GIDON M., BOURBON M., de GRACIANSKY P.-C., RUDKIEWICZ J.-L., MEGARD-GALLI J. and TRICART P. (1986) The continental margin of the Mesozoic Tethys in the Western Alps. Mar. Petrol. Geol., 3: 179-199.

LEONOV M.G. (1975) - Dikiy flish alpiyskoy oblasti (in Russian). Nauka, Moscow, Transact., 199.

LEŠKO B. (1960) - Paläogen der Klippenzone in der Ostslowakei (in Slovak with German summary). Geol. Sbor., 11 (1): 95-103.

LIATI A., FROITZHEIM N. and FANNING C.M. (2005) - Jurassic ophiolites within the Valais domain of the Western and Central Alps: geochronological evidence for re-rifting of oceanic crust. Contr. Miner. Petrol., 149: 446-461.

LISTER G.S., ETHERIDGE M.A. and SYMONDS P.A. (1986) - Detachment faulting and the evolution of passive continental margins. Geology, 14: 246-250.

LIU G. and EINSELE G. (1996) - Various types of olistostromes in a closing ocean basin, Tethyan Himalaya (Cretaceous, Tibet). Sedim. Geol., 104: 203-226.

MAAS K. and van GINKEL A.C. (1983) - Variscan olistostrome deposition and synsedimentary nappe emplacement, Valderon area, Cantabrian Mountains, Spain. Leidse Geol. Meded., 52 (2): 341-381.

MADZIN J., SÝKORA M. and SOTÁK J. (2011) - Products of the basaltic volcanism from the area of Osobitá peak in the West Tatra Mts. - their stratigraphy and character of the volcanic activity. Abstracts of the 9th CETeG meeting, Skalský Dvůr, Czech Rep., 13-17 April 2011. Trav. Géophys., 40: 47.

MAHEL' M. (1980) - The Peri-klippen zone: nearer characterization and significance (in Slovak with English summary). Miner. Slov., 12 (3): 193-207.

MAHEL' M. (1981) - Island character of the Klippen Belt; Vahicum - continuation of Southern Penninicum in West Carpathians. Geol. Zbor. Geol. Carpath., 32 (3): 293-305.
MAHEL' M. (1986) - Geologická stavba československých Karpát. 1 Paleoalpínske jednotky (in Slovak). Veda, Bratislava.

MAHEL' M. (1989) - The Klippen Belt from the aspect of the geodynamic model (in Slovak with English summary). Miner. Slov., 21: 99-108.

MANATSCHAL G. and BERNOULLI D. (1999) - Architecture and tectonic evolution of nonvolcanic margins: present-day Galicia and ancient Adria. Tectonics, 18: 1099-1119.

MANATSCHAL G. and MÜNTERER O. (2009) - A type sequence across an ancient magma-poor ocean-continent transition: the example of the western Alpine Tethys ophiolites. Tectonophysics, 473: 4-19.

MARKO F., VOJTKO R., PLAŠIENKA D., SLIVA L., JABLONSKÝ J., REICHWALDER P. and STAREK D. (2005) - A contribution to the tectonics of the Periklippen zone near Zázrivá (Western Carpathians). Slovak Geol. Mag., 11: 37-43.

MARRONI M., MOLLI G., MONTANINI A., OTTRIA G., PANDOLFI L. and TRIBUZIO R. (2002) - The External Ligurian units (Northern Apennines, Italy): from rifting to convergence of a fossil ocean-continent transition zone. Ofioliti, 27 (2): 119-131.

MARSCHALKO R. (1986) - Evolution and geotectonic significance of the Klippen Belt Cretaceous flysch in the Carpathian megastructure (in Slovak with English summary). Veda, Vyd. SAV, Bratislava.

MARSCHALKO R. and RAKÚS M. (1997) - Development of the Cretaceous flysch in the Klape unit and the recyclicity problem of the clastic material. In: Alpine Evolution of the Western Carpathians and Related areas (eds. D. Plašienka, J. Hók, J. Vozár and M. Elečko): 71-78. Internat. Conf., Introduct. articl. exc., Geol. Surv. Slov. Rep., Bratislava.

MARSCHALKO R., HAŠKO J. and SAMUEL O. (1979) - Záskalie breccias and genesis of olistostromes (in Slovak with English summary). Geol. Práce, Správy, 73: 75-88.

MELLO J., ed. (2011) -Explanations to the geological map of the Middle Váh Valley 1:50 000 (in Slovak with English summary). State Geol. Inst. D. Štúr, Bratislava.

MICHALÍK J. (2007) - Sedimentary rock record and microfacies indicators of the latest Triassic to mid-Cretaceous tensional development of the Zliechov Basin (Central Western Carpathians). Geol. Carpath., 58 (5): 443-453.

MICHALÍK J. and VLČKO J. (2011) - Genesis of the Middle Jurassic breccias in the Devín Unit of the Malé Karpaty Mts. (in Slovak with English summary). Miner. Slov., 43: 129-136.

MICHALÍK J., REHÁKOVÁ D. and ŽÍTT J. (1993) - Upper Jurassic and Lower Cretaceous facies, microplankton and crinoids in the Kuchyňa unit, Malé Karpaty Mts. Geol. Carpath., 44: 161-176.

MICHALÍK J., REHÁKOVÁ D. and SOTÁK J. (1994) - Environments and setting of the Jurassic/Lower Cretaceous Succession in the Tatric area, Malé Karpaty Mts. Geol. Carpath., 45: 45-56.

MICHALÍK J., REHÁKOVÁ D. and JABLONSKÝ J. (1996) Geodynamic setting of fluxoturbidites in West Carpathian Upper Jurassic and Lower Cretaceous sedimentary basins. Slovak Geol. Mag., (3-4): 325-329.

MIŠÍK M. (1979) - Sedimentological and microfacial study in the Jurassic of the Vršatec (castle) klippe (neptunic dykes, Oxfordian bioherm facies) (in Slovak with English summary). Záp. Karpaty, Geológia, 5: 7-56.

MIŠÍK M. (1986) - Petrographic-microfacial analysis of pebbles and interpretation of sources areas of the Jablonica conglomerates (Lower Miocene of the NW margin of the Malé Karpaty Mts.). Geol. Zbor. - Geol. Carpath., 37 (4): 405-448.

MIŠÍK M. (1994) - The Czorsztyn submarine ridge (Jurassic-Lower Cretaceous, Pieniny Klippen Belt): an example of a pelagic swell. Mitt. Österr. Geol. Ges., 86 (1993): 133-140.

MIŠÍK M. (1996) - O sedimentačnom priestore klapskej jednotky (in Slovak). Miner. Slov., 28: 73-75.

MIŠÍK M. and MARSCHALKO R. (1988) - Exotic conglomerates in flysch sequences: Examples from the West Carpathians. Mém. Soc. Géol. France, Nouv. Sér., 154: 95-113.

MIŠÍK M. and REHÁKOVÁ D. (2004) - Psefitické horniny (štrky, brekcie, zlepence) Západných Karpát (in Slovak). Veda, Vyd. SAV.

MIŠÍK M. and SÝKORA M. (1981) - Der pieninische exotische Rücken, rekonstruiert aus Geröllen karbonatischer Gesteine Kretazischer Konglomerate der Klippenzone und der Manín-Einheit (in Slovak with German summary). Záp. Karpaty, Geológia, 7: 7-111. 
MIŠÍK M., MOCK R. and SÝKORA M. (1977) - Die Trias der Klippen-Zone der Karpaten. Geol. Zbor. - Geol. Carpath., 28: 27-69.

MIŠÍK M., JABLONSKÝ J., MOCK R. and SÝKORA M. (1981) Konglomerate mit exotischem Material in dem Alb der Zentralen Westkarpaten - paläographische und tektonische Interpretation. Acta Geol. Geogr. Univ. Comen., Geologica, 37: 5-55.

MIŠÍK M., SÝKORA M., MOCK R. and JABLONSKÝ J. (1991) Paleogene Proč Conglomerates of the Klippen Belt in the Western Carpathians, material from Neopieninic exotic ridge. Acta Geol. Geogr. Univ. Comen., Geologica, 46: 9-101.

MIŠÍK M., SÝKORA M. and AUBRECHT R. (1994a) - Middle Jurassic scarp breccias with clefts filled by Oxfordian and Valanginian-Hauterivian sediments, Krasín near Dolná Súča (Pieniny Klippen Belt, Slovakia). Geol. Carpath., 45: 343-356.

MIŠÍK M., SÝKORA M., OŽVOLDOVÁ L. and AUBRECHT R. (1994b) - Horná Lysá (Vršatec) - a new variety of the Kysuca Succession in the Pieniny Klippen Belt. Miner. Slov., 26: 7-19.

MISSONI S. and GAWLICK H.-J. (2011) - Evidence for Jurassic subduction from the Northern Calcareous Alps (Berchtesgaden; Austroalpine, Germany). Int. J. Earth Sc. (Geol. Rd.), 100: 1605-1631.

MOSTLER H. and PAHR A. (1981) - Triasfossilien im „Cáker Konglomerat" von Goberling. Verh. Geol. B.-A., 1981 (2): 83-91.

MUTTI E., BERNOULLI D., RICCI LUCCHI F. and TINTERRI R. (2009) - Turbidites and turbidity currents from Alpine "flysch" to the exploration of continental margins. Sedimentology, 56: 267-318.

NAYLOR M.A. (1981) - Debris flows (olistostromes) and slumping on a distal passive continental margin: the Palombini limestone-shale sequence of the northern Apennines. Sedimentology, 28: 837-852.

NEMČOK J. (1980) - Non-traditional view of East-Slovakian Klippen Belt. Geol. Zbor. - Geol. Carpath., 31: 563-568.

NEMČOK J., KULLMANOVÁ A. and ĎURKOVIČ T. (1989) - Faciesand stratigraphical analyses of Gregorianka breccias in Klippen Belt of East Slovakia (in Slovak with English summary). Geol. Práce, Správy, 89: 11-37.

ORTNER H. (2003) - Cretaceous thrusting in the western part of the Northern Calcareous Alps (Austria) - evidences from synorogenic sedimentation and structural data. Mitt. Österr. Geol. Ges., 94 (2001) 63-77.

OSZCZYPKO N. (1992) - Late Cretaceous through Paleogene evolution of Magura Basin. Geol. Carpath., 43: 333-338.

OSZCZYPKO N. and OSZCZYPKO-CLOWES M. (2009) - Stages in the Magura Basin: a case study of the Polish sector (Western Carpathians). Geodin. Acta, 22 (1-3): 83-100.

OSZCZYPKO N. and OSZCZYPKO-CLOWES M. (2010) - The Paleogene and early Neogene stratigraphy of the Beskid Sądecki Range and Lubovnianska Vrchovina (Magura Nappe, Western Outer Carpathians). Acta Geol. Pol., 60 (3): 317-348.

OSZCZYPKO N., JUREWICZ E. and PLAŠIENKA D. (2010) - Tectonics of the Klippen Belt and Magura Nappe in the eastern part of the Pieniny Mts. (Western Carpathians, Poland and Slovakia) - new approaches and results. Sc. Ann., School Geol., Aristotle Univ. Thessaloniki. Proc. XIX CBGA Congress, Thessaloniki, Greece. Spec. Vol., 100: 221-229.

PICHAF.J., STRÁNÍK Z. and KREJČÍ O. (2006) - Geology and hydrocarbon resources of the Outer Western Carpathians and their foreland, Czech Republic. AAPG Mem., 84: 49-175.

PINI G.A. (1999) - Tectonosomes and olistostromes in the Argille Scagliose of the northern Apennines, Italy. GSA Spec. Pap., 335.

PINI G.A., OGATA K., CAMERLENGHI A., FESTA A., LUCENTE C.C. and CODEGONE G. (2012) - Sedimentary mélanges and fossil mass-transport complexes: a key for better understanding submarine mass movements? In: Submarine Mass Movements and their Consequences (eds. Y. Yamada, K. Kawamura, K. Ikehara, Y. Ogawa, R. Urgeles, D. Mosher, J. Chaytor and M. Strasser): 585-594. 5th International Symposium, Chapter 52. Advances in natural and technological hazards research 31, Springer Sc. and Business Media B.V.

PLAŠIENKA D. (1987) - Lithological, sedimentological and paleotectonic pattern of the Borinka Unit in the Little Carpathians (in Slovak with English summary). Miner. Slov., 19: 217-230.

PLAŠIENKA D. (1990) - Regional shear and transpression zones in the Tatric unit of the Little Carpathians (in Slovak with English summary). Miner. Slov., 22: 55-62.
PLAŠIENKA D. (1995a) - Passive and active margin history of the northern Tatricum (Western Carpathians, Slovakia). Geol. Rd., 84: 748-760.

PLAŠIENKA D. (1995b) - Mesozoic evolution of Tatric units in the Malé Karpaty and Považský Inovec Mts.: implications for the position of the Klape and related units in western Slovakia. Geol. Carpath., 46: 101-112.

PLAŠIENKA D. (1995c) - Origin and structural position of the Upper Cretaceous sediments in the northern part of the Považský Inovec Mts. Part 2: Structural geology and paleotectonic reconstruction (in Slovak with English summary). Miner. Slov., 27: 179-192.

PLAŠIENKA D. (1997) - Cretaceous tectonochronology of the Central Western Carpathians (Slovakia). Geol Carpath., 48: 99-111.

PLAŠIENKA D. (1999) - Tectonochronology and paleotectonic evolution of the Central Western Carpathians during the Jurassic and Cretaceous (in Slovak with English summary). Veda, Bratislava.

PLAŠIENKA D. (2002) - Origin and growth of the West Carpathian orogenic wedge during the Mesozoic. Geol. Carpath., 53 (Spec. Issue): $132-135$.

PLAŠIENKA D. (2003) - Dynamics of Mesozoic pre-orogenic rifting in the Western Carpathians. Mitt. Österr. Geol. Ges., 94 (2001): 79-98.

PLAŠIENKA D. (2012) - Early stages of structural evolution of the Carpathian Klippen Belt (Slovakian Pieniny sector). Miner. Slov., 44 (1): $1-16$.

PLAŠIENKA D. and MIKUŠ M. (2010) - Geological structure of the Pieniny and Šariš sectors of the Klippen Belt between the Litmanová and Drienica villages in Eastern Slovakia (in Slovak with English summary). Miner. Slov., 42 (2): 155-178.

PLAŠIENKA D. and PROKEŠOVÁ R. (1996) - Towards an evolutionary tectonic model of the Krížna cover nappe (Western Carpathians, Slovakia). Slovak Geol. Mag., 2 (3-4): 279-286.

PLAŠIENKA D., MICHALÍK J., GROSS P. and PUTIŠ M. (1991) Paleotectonic evolution of the Malé Karpaty Mts. - an overview. Geol. Carpath., 42: 195-208.

PLAŠIENKA D., MARSCHALKO R., SOTÁK J., UHER P. and PETERČÁKOVÁ M. (1994) - Origin and structural position of Upper Cretaceous sediments in the northern part of the Považský Inovec Mts. Part 1: Lithostratigraphy and sedimentology (in Slovak with English summary). Miner. Slov., 26: 311-334.

PLAŠIENKA D., SOTÁK J. and SPIŠIAK J. (1995) - Penninic units of the Central Western Carpathians: lithological, structural and metamorphic signatures. Geol. Soc. Greece, Sp. Publ. 4/1, Proc. XV Congr. CBGA: 80-85.

PLAŠIENKA D., HAVRILA M., MICHALÍK J., PUTIŠ M. and REHÁKOVÁ D. (1997) - Nappe structure of the western part of the Central Carpathians. In: Alpine Evolution of the Western Carpathians and Related Areas (eds. D. Plašienka, J. Hók, J. Vozár and M. Elečko): 139-161. Internat. Conf., Introduct. articl. exc., Geol. Survey Slov. Rep., D. Štúr Publ., Bratislava.

PLAŠIENKA D., SOTÁK J. and PROKEŠOVÁ R. (1998) - Structural profiles across the Šambron-Kamenica Periklippen Zone of the Central Carpathian Paleogene Basin in NE Slovakia. Miner. Slov., 29: 173-184.

PLAŠIENKA D., SOTÁK J., JAMRICHOVÁ M., HALÁSOVÁ E., PIVKO D., JÓZSA Š., MADZIN J. and MIKUŠ V. (2012) - Structure and evolution of the Pieniny Klippen Belt demonstrated along a section between Jarabina and Litmanová villages in Eastern Slovakia. Miner. Slov., 44 (1): 17-38.

POBER E. and FAUPL P. (1988) - The chemistry of detrital chromian spinels and its implications for the geodynamic evolution of the Eastern Alps. Geol. Rd., 77: 641-670.

POLÁK M., ed. (2012) - Explanations to the geological map of the Malé Karpaty Mts. 1:50 000 (in Slovak with English summary). State Geol. Inst. D. Štúr, Bratislava.

POTFAJ M. (1993) - Position and role of the Biele Karpaty Unit in the Flysch zone of the West Carpathians (in Slovak with English summary). Geol. Práce, Správy, 98: 55-78.

POTFAJ M. (1998) - Geodynamics of the Klippen Belt and Flysch Belt of the Western Carpathians. In: Geodynamic Development of the Western Carpathians (ed. M. Rakú.): 143-154. Geol. Surv. Slov. Rep., D. Štúr Publ., Bratislava.

PROKEŠOVÁ R., PLAŠIENKA D. and MILOVSKÝ R. (2012) - Structural pattern and emplacement mechanisms of the Krížna cover nappe (Western Carpathians, Slovakia). Geol. Carpath., 63 (1): 13-32. 
PREY S. (1977) - Flyscherscheinungen in den „flyschartigen Serien“ des östlichen Tauernnordrandes. Verh. Geol. B.-A., 1977 (3): 313-320.

PUTIŠ M., SULÁK M., GAWLICK H.-J. and BOJAR A.-V. (2006) Infratatricum of the Považský Inovec Mts. (Western Carpathians): geodynamic evolution of continental margin in the vicinity of the oceanic Penninicum (in Slovak with English summary). Miner. Slov., 38 (1): 7-28.

PUTIŠ M., GAWLICK H.-J., FRISCH W. and SULÁK M. (2008) - Cretaceous transformation from passive to active continental margin in the Western Carpathians as indicated by the sedimentary record in the Infratatric unit. Int. J. Earth Sc. (Geol. Rd.), 97: 799-819.

RAKÚS M. and HÓK J. (2005) - The Manín and Klape units: Lithostratigraphy, tectonic classification, paleogeographic position and relationship to Vahicum (in Slovak with English summary). Miner. Slov., 37: 9-26.

RAKÚS M. and MARSCHALKO R. (1997) - Position of the Manín, Drietoma and Klape units at the boundary of the Central and Outer Carpathians. In: Alpine Evolution of the Western Carpathians and Related Areas (eds. D. Plašienka, J. Hók, J. Vozár and M. Elečko): 79-97. Internat. Conf. "Carpathian Geology 2000", Introduct. Art. Excurs., Geol. Surv. Slov. Rep., Bratislava.

RATSCHBACHER L., BEHRMANN J.H. and PAHR A. (1990) Penninic windows at the eastern end of the Alps and their relation to the intra-Carpathian basins. Tectonophysics, 172: 91-105.

RATSCHBACHER L., DINGELDEY C., MILLER C., HACKER B.R. an McWILLIAMS M.O. (2004) - Formation, subduction, and exhumation of Penninic oceanic crust in the Eastern Alps: time constraint from ${ }^{40} \mathrm{Ar} /{ }^{39} \mathrm{Ar}$ geochronology. Tectonophysics, 394: 155-170.

REHÁKOVÁ D., MATYJA B.A., WIERZBOWSKI A., SCHLÖGL J., KROBICKI M. and BARSKI M. (2011) - Stratigraphy and microfacies of the Jurassic and lowermost Cretaceous of the Veliky Kamenets section (Pieniny Klippen Basin, Carpathians, Western Ukraine). Vol. Jurassica, 9: 61-104.

SALAJ J. (2006) - Microbiostratigraphy of the Gosau development in the Klape Unit, Western Carpathian Paleoalpine accretionary belt. Miner. Slov., 38 (1): 1-6.

SALAJ J. and BEGAN A. (1983) - Senonian and Paleogene palaeogeographic and tectonic development of the Myjavská Pahorkatina Upland (West Carpathians, Czechoslovakia). Zitteliana, 10: 173-181.

SCHEIBNER E. (1967) - Nižná Subunit - new stratigraphical sequence of the Klippen Belt (West Carpathians). Geol. Sbor., 18 (1): 133-140.

SCHLÖGL J., MICHALÍK J., PLAŠIENKA D., AUBRECHT R. REHÁKOVÁ D., TOMAŠOVÝCH A., BUČOVÁ J., MIKUŠ V., SÝKORA M. and GOLEJ M. (2009) - Jurassic to Lower Cretaceous deposits of the Pieniny Klippen Belt and Manín Unit in the Middle Váh Valley (Biele Karpaty and Strážovské vrchy Mts, Western Slovakia). Geologia, 35 (3/1): 119-181.

SCHMID S.M., FÜGENSCHUH B., KISSLING E. and SCHUSTER R. (2004) - Tectonic map and overall architecture of the Alpine orogen. Ecl. Geol. Helv., 97: 93-117.

SCHMID S.M., BERNOULLI D., FÜGENSCHUH B., MATENCO L., SCHEFER S., SCHUSTER R., TISCHLER M. and USTASZEWSKI K. (2008) - The Alpine-Carpathian-Dinaridic orogenic system: correlation and evolution of tectonic units. Swiss J. Geosc., 101 (1): 139-183.

SCHNABEL W. (1992) - New data on the Flysch zone of the Eastern Alps in the Austrian sector and new aspects concerning the transition to the Flysch Zone of the Carpathians. Cret. Res., 13: 405-419.

SIKORA W. (1971) - Esquisse de la tectogénèse de la zone des Klippes des Pieniny en Pologne d'après de nouvelles données géologiques (in Russian with French summary). Rocz. Pol. Tow. Geol., 4 (1): 221-239.

SIKORA W. (1974) - The Pieniny Klippen Belt (Polish Carpathians). In Tectonics of the Carpathian-Balkan regions (ed. M. Mahel'): 177-180. Geol. Inst. D. Štúr, Bratislava.

SILVER E.A. and BEUTNER E.C. (1980) - Melanges. Geology, 8 (1): $32-34$

SOTÁK J., RUDINEC R. and SPIŠIAK J. (1993a) - The Penninic "pull-apart" dome in the pre-Neogene basement of the Transcarpathian Depression (Eastern Slovakia). Geol. Carpath., 44: 11-16.
SOTÁK J., PLAŠIENKA D., SPIŠIAK J. and UHER P. (1993b) - Neptunian carbonate dykes hosted by basic volcanic rocks in the Považský Inovec Mts. (in Slovak with English summary). Miner. Slov., 25: 193-201.

SOTÁK J., SPIŠIAK J. and BIROŇ A. (1994) - Metamorphic sequences with "Bündnerschiefer" lithology in the pre-Neogene basement of the East Slovakian Basin. Mitt. Österr. Geol. Ges., 86 (1993): 111-120.

SPIŠIAK J., PLAŠIENKA D., BUČOVÁ J., MIKUŠ T. and UHER P. (2011) - Petrology and palaeotectonic setting of Cretaceous alkaline basaltic volcanism in the Pieniny Klippen Belt (Western Carpathians, Slovakia). Geol. Quart., 55 (1): 27-48.

STAMPFLI G.M. (1994) - Exotic terrains in the Alps: a solution for a single Jurassic ocean. Schweiz. Miner. Petrogr. Mitt., 74: 449-452.

STAMPFLI G.M. (1996) - The Intra-Alpine terrain: a Paleotethyan remnant in the Alpine Variscides. Ecl. Geol. Helv., 89: 13-42.

STAREK D., AUBRECHT R., SLIVA L. and JÓZSA Š. (2010) - Sedimentary analysis of the Cretaceous flysch sequences at the Zemianska Dedina locality (Nižná Unit, Pieniny Klippen Belt, northern Slovakia). Miner. Slov., 42: 179-188.

STRÁNÍK Z. (1965) - Zur Geologie des Magura-Flysches im Gebirge Čerchovské pohoří und Ondavská vrchovina (in Slovak with German summary). Sbor. Geol. Vied, rad ZK, 3: 125-178.

ŚLACZKA A., HOECK V. and IONESCU C. (2011) - Mesozoic slope-aprons and submarine fans in the NE Tauern Window (Austria). Austrian J. Earth Sc., 104 (2): 58-72.

TOMEK Č. (1993) - Deep crustal structure beneath the central and inner West Carpathians. Tectonophysics, 226: 417-431.

TOLLMANN A. (1977) - Geologie von Österreich. Band I: Die Zentralalpen. Franz Deuticke, Wien.

TRÜMPY R. (1980) - Geology of Switzerland, a guide book. Part A: an outline of the geology of Switzerland. Schweiz. Geol. Komm., Wepf and Co. Publ., Basel and New York

TRÜMPY R. (1988) - A possible Jurassic-Cretaceous transform system in the Alps and the Carpathians. GSA Spec. Pap., 218: 93-109.

UHER P. and PUSHKAREV Yu. (1994) - Granitic pebbles of the Cretaceous flysch of the Pieniny Klippen Belt, Western Carpathians: $\mathrm{U} / \mathrm{Pb}$ zircon ages. Geol. Carpath., 45: 375-378.

UHLIG V. (1907) - Über die Tektonik der Karpathen. Sitzungsber. Kaiser. Akad. Wiss., mat.-naturwiss. K1., 116, part I: 871-982.

VANNUCCHI P. and BETTELLI G. (2010) - Myths and recent progress regarding the Argille Scagliose, Northern Apennines, Italy. Internat. Geol. Rev., 52 (10-12): 1106-1137.

WAGREICH M. (2001) - A 400-km-long piggyback basin (Upper Aptian-Lower Cenomanian) in the Eastern Alps. Terra Nova, 13: 401-406.

WAGREICH M. (2003) - A slope-apron succession filling a piggyback basin: the Tannheim and Losenstein Formations (Aptian-Cenomanian) of the eastern part of the Northern Calcareous Alps (Austria). Mitt. Österr. Geol. Ges., 93 (2000): 31-54.

WAGREICH M. and MARSCHALKO R. (1995) - Late Cretaceous to Early Tertiary palaeogeography of the Western Carpathians (Slovakia) and the Eastern Alps (Austria): implications from heavy mineral data. Geol. Rd., 84: 187-199.

WANG C.-S. (1981) - Olistostrome and melange in the evolution of subduction complexes. Mem. Geol. Soc. China, 1981 (4): 55-65.

WEISSERT H. and BERNOULLI D. (1985) - A transform margin in the Mesozoic Tethys: evidence from the Swiss Alps. Geol. Rd., 74: 665-679.

WIECZOREK J. (2000) - Mesozoic evolution of the Tatra Mountains (Carpathians). Mitt. Ges. Geol. Bergbaustud. Österr., 44: 241-262.

WIERZBOWSKI A., JAWORSKA M. and KROBICKI M. (1999) - Jurassic (Upper Bajocian-Lowest Oxfordian) ammonitico rosso facies in the Pieniny Klippen Belt, Carpathians, Poland: its fauna, age, microfacies and sedimentary environment. Studia Geol. Pol., 115: 7-74.

WINKLER W. and ŚLĄCZKA A. (1994) - A Late Cretaceous to Paleogene geodynamic model for the Western Carpathians in Poland. Geol. Carpath., 45: 71-82.

ŽEC B., ed. (1997) - Explanations to the geological map of the Vihorlatské and Humenské vrchy Mts. 1:500,000 (in Slovak with English summary). Geol. Služba SR, Vyd. D. Štúra, Bratislava. 